\title{
Lipid-Lowering efficacy of the PCSK9 inhibitor Evolocumab (AMG 145) in patients with Type 2 Diabetes Mellitus: a meta-analysis
}

Running title: evolocumab in patients with T2DM

Naveed Sattar, PhD, ${ }^{*}$ David Preiss, PhD, ${ }^{2}$ Jennifer G. Robinson, MD ${ }^{3}$ C. Stephen Djedjos, MD, ${ }^{4}$ Mary Elliott, MSc, ${ }^{5}$ Ransi Somaratne, MD, ${ }^{4}$ Scott M. Wasserman, MD, ${ }^{4}$ Frederick J. Raal, $\mathrm{PhD}^{6}$

${ }^{1}$ Institute of Cardiovascular and Medical Sciences, University of Glasgow, Glasgow, UK

${ }^{2}$ Clinical Trial Service Unit and Epidemiological Studies Unit, Nuffield Department of Population Health, University of Oxford, Oxford, UK

${ }^{3}$ Departments of Epidemiology and Medicine, College of Public Health, University of Iowa, Iowa City, IA, USA

${ }^{4}$ Amgen Inc., Thousand Oaks, CA, USA

${ }^{5}$ Amgen Ltd., Cambridge, UK

${ }^{6}$ Department of Medicine, University of Witwatersrand Medical School, Carbohydrate \& Lipid Metabolism Research Unit, Faculty of Health Sciences, University of Witwatersrand, Johannesburg, South Africa

* joint lead authors

\section{Address correspondence to:}

Professor Naveed Sattar

BHF Glasgow Cardiovascular Centre, 126 University Avenue, Glasgow, UK, G12 8TA

Email: $\quad$ naveed.sattar@glasgow.ac.uk

Phone: $\quad$ +441413303419

Word count: 2,835 (excludes acknowledgements, contributions, disclosures) (abstract 250)

Figures: $\quad 3$ (and 1 supplementary figure)

Tables: $\quad 3$ (and 2 supplementary tables) 


\section{Summary}

Background: Patients with type 2 diabetes mellitus (T2DM) have elevated cardiovascular risk. PCSK9 monoclonal antibodies have been shown to reduce LDL-C and other lipids, but specific efficacy for patients with diabetes is unknown.

Methods: We studied the effect of the PCSK9 inhibitor evolocumab on lipid parameters (LDL-C, non-HDL-cholesterol, total cholesterol, triglycerides, lipoprotein(a), HDL-C) in patients with and without T2DM. We searched Medline and EMBASE (2012-2015) to identify 12-week phase 3 trials of subcutaneous evolocumab therapy once every 2 weeks or once monthly versus placebo or ezetimibe. We used random effects meta-analyses to combine data. Subgroups of T2DM patients (by glycaemia, insulin use, renal function and cardiovascular disease status) were also compared.

Findings: Data were available for 413 patients with, and 2,119 without, T2DM in three trials. After 12 weeks of evolocumab therapy, mean (95\% CI) reductions in LDL-C were 60\% (51$69 \%$ ) versus placebo and 39\% (32-47\%) versus ezetimibe in patients with T2DM.

Reductions were 66\% (62-70\%) and 40\% (36-45\%), respectively, in patients without T2DM. In patients with T2DM, reductions observed with evolocumab compared with placebo and ezetimibe were 55\% (47-63\%) and 34\% (26-41\%) for non-HDL-cholesterol, 38\% (32-44\%) and $24 \%(16-31 \%)$ for total cholesterol, $31 \%$ (25-37\%) and 26\% (16-35\%) for lipoprotein(a), respectively; increases in HDL-C of $8 \%(4-11 \%)$ and $8 \%$ (4-13\%), respectively, were also observed. Findings across diabetes subgroups were comparable.

Interpretation: Evolocumab markedly reduces atherogenic lipoproteins in T2DM, an effect consistent across T2DM subgroups, and comparable to changes in patients without T2DM. Cardiovascular outcomes trials are ongoing.

Funding: Amgen Inc. 


\section{Research in context}

Evidence before this study: Patients with T2DM are known to have high CVD event risks, and have an atherogenic lipid profile with low HDL-cholesterol and elevated triglyceride-rich apolipoprotein B-containing lipoproteins, and thus high non-HDL-cholesterol. It is unclear how effective PCSK9 inhibition is in this context. We searched Medline using the terms 'PCSK9 inhibitor' and 'diabetes' from 01/01/2012 to 19/10/2015 to establish what data had been published regarding the effect of PCSK9 inhibition on lipids in patients with type 2 diabetes (T2DM) and concluded that no robust data were yet available.

Added value of this study: In a pooled analysis of three trials with 413 patients with type 2 diabetes, the PCSK9 inhibitor evolocumab reduced LDL-cholesterol by $60 \%$, non-HDLcholesterol by $55 \%$, total cholesterol by $38 \%$, triglycerides by $23 \%$, lipoprotein(a) by $31 \%$, and increased HDL-C by $8 \%$ at 12 weeks compared to placebo. Evolocumab also lowered LDL-cholesterol by 39\% compared to ezetimibe therapy. These reductions were not statistically different from the reductions noted in 2,119 participants without diabetes in the same trials. The reductions in LDL-cholesterol were similar in those with diabetes regardless of the use of insulin, the presence or absence of CVD, and the levels of $\mathrm{HbA}_{1 \mathrm{c}}$ and eGFR at baseline.

Implications of all the available evidence: The PCSK9 inhibitor evolocumab markedly reduced levels of atherogenic lipoproteins in patients with T2DM. If cardiovascular benefit is demonstrated in major endpoint trials, PCSK9 inhibition represents a promising therapy to reduce CVD risk further in patients with T2DM. 


\section{Introduction}

Diabetes mellitus is well recognised as a key risk factor in the development of cardiovascular disease. Extensive data from the Emerging Risk Factor Collaboration indicate that individuals with diabetes are at double the risk of both myocardial infarction and stroke compared with those without diabetes in analyses adjusted for age, sex, smoking status, and body mass index. ${ }^{1}$ Furthermore, vascular-related deaths explain at least half of the years of life lost by individuals with type 2 diabetes (T2DM). ${ }^{1}$

Lowering LDL-cholesterol (LDL-C) with statins as well as ezetimibe provides cardiovascular benefit for those with T2DM. In the Collaborative Atorvastatin Diabetes Study (CARDS) (n $=2,838$ ), atorvastatin $10 \mathrm{mg}$ daily lowered LDL-C by $1.2 \mathrm{mmol} / \mathrm{L}$ (about $40 \%$ ) compared with placebo and led to a $37 \%$ reduction in the occurrence of major cardiovascular events in patients with T2DM but no history of cardiovascular disease over 3.9 years. ${ }^{2}$ Data from the Cholesterol Treatment Trialists' Collaboration analysis of 14 major statin trials $(n=18,686)$ confirmed this benefit by demonstrating that those with diabetes were at $9 \%$ lower risk of allcause death and $21 \%$ lower risk of major cardiovascular events per $1 \mathrm{mmol} / \mathrm{L}$ LDL-C reduction achieved with statin therapy. ${ }^{3}$ In the recently published IMPROVE-IT trial, which compared combination therapy of daily ezetimibe and simvastatin with simvastatin monotherapy in patients following a recent acute coronary syndrome, a subgroup analysis of patients with diabetes $(n=4,933)$ showed that ezetimibe therapy led to a further $0.4 \mathrm{mmol} / \mathrm{L}$ lowering of LDL-C and a $14 \%$ reduction in major cardiovascular events. ${ }^{4}$

Despite improvements in care and reductions in mortality risk, cardiovascular risk remains elevated in patients with T2DM, which leads to a reduction in life expectancy ${ }^{5}$, and additional 
strategies are needed to address this risk. Both LDL-cholesterol and non-HDL-cholesterol are associated with cardiovascular events in patients with $\mathrm{T}_{2} \mathrm{DM}^{6}$ and they typically have an atherogenic lipid profile (namely low HDL-cholesterol and high triglyceride-rich apolipoprotein B-carrying lipoproteins with only moderately elevated LDL-C levels). ${ }^{7}$ Monoclonal antibodies which inhibit proprotein convertase subtilisin/kexin type 9 (PCSK9) ${ }^{8}$ have been shown to markedly reduce LDL-C. ${ }^{9}$ However the efficacy of PCSK9 inhibitors in patients with T2DM, more often characterized by elevated non-HDL-C, rather than LDL-C, is uncertain. We investigated the effects of a PCSK9 inhibitor, evolocumab, on lipoproteins in patients with and without T2DM.

\section{Methods}

\section{Study design}

In this study we pooled data for 12 week phase 3 trials comparing evolocumab therapy to placebo and/or ezetimibe therapy which met our search criteria. On $27^{\text {th }}$ November 2015 , two authors (NS and DP) searched Medline and EMBASE without language restriction from $1^{\text {st }}$ January 2012 to $28^{\text {th }}$ February 2015 using the terms 'AMG 145 ' or 'evolocumab', limited to randomised trials conducted in adult humans but excluding trials conducted in patients with homozygous familial hypercholesterolaemia, to identify the relevant trials (see

Supplementary Figure 1). As we had access to individual participant data, the literature search was conducted to identify trials but not to extract data.

The 12 week pivotal phase 3 trials for evolocumab meeting our search criteria included three studies - the LDL-C Assessment with PCSK9 Monoclonal Antibody Inhibition Combined With Statin Therapy (LAPLACE-2, NCT01763866) trial, ${ }^{10}$ the Reduction of LDL-C With 
PCSK9 Inhibition in Heterozygous Familial Hypercholesterolemia Disorder Study-2 (RUTHERFORD-2, NCT01763918), ${ }^{11}$ and the Goal Achievement after Utilizing an AntiPCSK9 Antibody in Statin Intolerant Subjects (GAUSS-2, NCT01763905) trial. ${ }^{12}$ A fourth study, the Monoclonal Antibody Against PCSK9 to Reduce Elevated LDL-C in Subjects Currently Not Receiving Drug Therapy for Easing Lipid Levels-2 (MENDEL-2, NCT01763827) trial, was not considered as patients with T2DM were excluded from that placebo- and ezetimibe-controlled monotherapy study. ${ }^{13}$ The primary results from these trials have already been published along with detailed descriptions of their respective study designs. ${ }^{10-12}$ Briefly, LAPLACE-2 was a combination therapy trial conducted in 1,896 patients with primary hypercholesterolaemia to study the effect of evolocumab versus placebo or ezetimibe when added to stable statin therapy. In the RUTHERFORD-2 trial, evolocumab was studied in 329 patients with heterozygous familial hypercholesterolaemia on stable lipid-lowering therapy and with fasting LDL-C concentrations $\geq 2.6 \mathrm{mmol} / \mathrm{L}$. The GAUSS-2 trial investigated the effect of evolocumab in 307 patients with hypercholesterolaemia who could tolerate no, low, or atypical dose statin. This is summarised in Figure 1. Participants from the three trials provided written informed consent and the trials were approved by all relevant ethics committees and regulatory bodies.

\section{Randomisation and masking}

In the LAPLACE-2 combination therapy trial, patients were randomised to one of 24 treatment arms. First, patients were randomised to one of five statins/statin doses. Subsequently, patients were randomised to evolocumab (140 mg every two weeks or $420 \mathrm{mg}$ monthly), ezetimibe (10 mg or placebo daily; atorvastatin patients only), or placebo (every two weeks or monthly). ${ }^{10}$ In the RUTHERFORD-2 trial, patients were randomised $(1: 1: 2: 2)$ to subcutaneous (SC) placebo biweekly; SC placebo monthly; evolocumab $140 \mathrm{mg}$ biweekly; 
or evolocumab $420 \mathrm{mg}$ monthly. ${ }^{11}$ In the GAUSS-2 trial, patients were randomised (1:1:2:2) to ezetimibe and SC placebo biweekly; ezetimibe and SC placebo monthly; oral placebo and evolocumab $140 \mathrm{mg}$ biweekly; or oral placebo and evolocumab $420 \mathrm{mg}$ monthly. ${ }^{12}$ Randomisation sequences were generated by computer for the three trials by the sponsor, Amgen. Patients, study personnel, investigators, and Amgen study staff were blinded to treatment assignment within dose frequency groups. Each trial was overseen by an independent data monitoring committee.

\section{Study procedures}

The main purpose of this analysis was to compare the efficacy of 12 weeks of evolocumab treatment (versus placebo or ezetimibe) on lipid parameters in 413 patients with T2DM compared with 2,119 without T2DM. The selected lipid parameters were LDL-C, non-HDLcholesterol (non-HDL-C), total cholesterol, triglycerides, lipoprotein(a), and HDL-C. In addition, the effects of evolocumab across T2DM subgroups, namely the presence or absence of cardiovascular disease, use or no use of insulin therapy, $\mathrm{HbA}_{1 \mathrm{c}} \geq$ or $<$ median, and eGFR $\geq$ or $<60 \mathrm{~mL} / \mathrm{min} / 1 \cdot 73 \mathrm{~m}^{2}$ were investigated.

Evolocumab or placebo was administered by subcutaneous injection either in the clinic or by self-administration at the patient's home. The doses investigated (which were randomly allocated) were $140 \mathrm{mg}$ biweekly or 420mg monthly. Ezetimibe 10mg daily (oral) and placebo (oral and/or SC) were the comparator treatments. The previously published coprimary lipid endpoints in these three trials typically consisted of the mean reduction in LDL$\mathrm{C}$ at both week 12 and at the mean of weeks 10 and 12, but these results were generally very similar, so only 12 week data are presented in the current analysis. In addition, data from biweekly and monthly dosing regimens for evolocumab were similar and these were therefore 
also pooled. Patients receiving monthly SC injections administered the last dose of study medication or placebo at week 8 and those on biweekly treatment at week 10 .

Fasting ( $\geq 9$ hours) lipid levels were measured at a central laboratory (Medpace Reference Laboratories, Cincinnati, USA and Leuven, Belgium). LDL-C was determined by the Friedewald formula (LDL-C $[\mathrm{mmol} / \mathrm{L}]=$ total cholesterol $[\mathrm{mmol} / \mathrm{L}]-\mathrm{HDL}-$ cholesterol $[\mathrm{mmol} / \mathrm{L}]$ - triglycerides $[\mathrm{mmol} / \mathrm{L}] / 2 \cdot 2)$, unless calculated $\mathrm{LDL}-\mathrm{C}$ was $<1 \cdot 0 \mathrm{mmol} / \mathrm{L}$ or triglyceride levels were $>4.5 \mathrm{mmol} / \mathrm{L}$, in which case LDL-C was measured after preparative ultracentrifugation. Non-HDL-cholesterol (mmol/L) was calculated by subtracting HDLcholesterol (mmol/L) from total cholesterol ( $\mathrm{mmol} / \mathrm{L})$.

$\mathrm{T} 2 \mathrm{DM}$ at baseline was defined as medical history of diabetes, baseline $\mathrm{HbA}_{1 \mathrm{c}} \geq 6 \cdot 5 \%(48$ $\mathrm{mmol} / \mathrm{mol})$, baseline fasting plasma glucose $>125 \mathrm{mg} / \mathrm{dL}(7.0 \mathrm{mmol} / \mathrm{L})$, or use of medication for an indication of T2DM (categorised into three groups according to the WHO Drug Dictionary namely insulins and analogues; blood glucose lowering drugs excluding insulins; and other drugs used in diabetes).

\section{Statistical analysis}

Analyses were conducted with individual participant data. Data were included for all participants who received at least one dose of study medication. For all analyses, dose frequencies were combined. A repeated measures model with an unstructured covariance matrix, containing terms for treatment group, scheduled visit, dose frequency, stratification factor, and the interaction between scheduled visit and treatment was used to estimate the treatment difference within each study and statin cohort. These study-specific results were then pooled as follows. For the placebo versus evolocumab comparison, all patients from 
studies with a placebo control were combined - i.e., all patients from the RUTHERFORD-2 study ${ }^{11}$ and all patients from the LAPLACE-2 study ${ }^{10}$ who received evolocumab or placebo respectively were combined. For the ezetimibe versus evolocumab comparison, all patients from studies with an ezetimibe control were combined - i.e., all patients from the GAUSS-2 study, ${ }^{12}$ and patients from the two atorvastatin cohorts $(10 \mathrm{mg} /$ day and $80 \mathrm{mg} /$ day only) from the LAPLACE-2 study were combined. ${ }^{10}$ For the latter study, this was due to the fact that only patients in the atorvastatin cohorts could be randomised to also receive ezetimibe.

Data were analysed using a random effects meta-analysis and are reported as percentage change. The estimates were combined using the Dersimonian-Laird random effect estimator. All $P$-values reported are nominal and no multiplicity adjustment was conducted. Data were analysed using SAS version 9.3 and all $P$-values were two-sided with $<0.05$ considered to be significant. [RUTHERFORD-2 NCT01763918; GAUSS-2 NCT01763905; LAPLACE-2 NCT01763866].

\section{Role of the funding source}

Amgen funded the three trials, which were designed in collaboration with each trial's investigators, and Amgen was responsible for data collection and analysis.

\section{Results}

Of 2,532 patients studied in the three trials, 413 were known to have T2DM at baseline while 2,119 did not have T2DM. The numbers allocated to placebo, ezetimibe, or evolocumab are shown in Figure 1 and Table 1. 
Changes in LDL-C and other lipids in individual arms from each trial are provided in Supplementary Table 1 . After 12 weeks of treatment, mean changes in LDL-C in evolocumab versus placebo-treated patients were comparable with considerably greater reductions on evolocumab: $-60 \%$ in patients with T2DM versus $-66 \%$ in patients without T2DM (see Table 2 and Figure 2). Mean changes for evolocumab versus ezetimibe in LDL-C were also comparable with greater reductions on evolocumab: $-39 \%$ in patients with T2DM and $-40 \%$ in patients without T2DM. Comparable reductions in non-HDL-C, total cholesterol, triglycerides, and lipoprotein(a), and increases in HDL-C also occurred in T2DM patients and those without T2DM treated with evolocumab compared with placebo or ezetimibe. For nonHDL-C, the mean changes in evolocumab versus placebo-treated patients were $-55 \%$ for patients with T2DM and $-58 \%$ for patients without T2DM; these changes were $-34 \%$ and $35 \%$, respectively, for evolocumab versus ezetimibe. For total cholesterol, mean changes in evolocumab versus placebo-treated patients were $-38 \%$ in patients with T2DM and $-40 \%$ in patients without T2DM; mean changes versus ezetimibe were $-24 \%$ and $-25 \%$, respectively. For triglycerides, mean changes in evolocumab versus placebo-treated patients were $-23 \%$ in patients with T2DM and $-17 \%$ in patients without T2DM; mean changes versus ezetimibe were $-9 \%$ and $-3 \%$, respectively. For lipoprotein(a), mean changes in evolocumab versus placebo-treated patients were $-31 \%$ in patients with T2DM and $-29 \%$ in patients without T2DM; mean changes versus ezetimibe were $-26 \%$ and $-30 \%$, respectively. For HDL-C, mean changes in evolocumab versus placebo-treated patients were $8 \%$ in patients with T2DM and $7 \%$ in patients without T2DM; mean changes versus ezetimibe were $8 \%$ and $6 \%$, respectively. For all lipid parameters, $\mathrm{p}$ values for the interaction at week 12 between those with or without T2DM were non-significant. 
LDL-C reductions on evolocumab were comparable at approximately 50-60\% across all T2DM subgroups that were investigated (Figure 3 and Supplementary Table 2).

\section{Safety of evolocumab therapy}

Adverse event rates, including injection site reactions and myalgia, in evolocumab-treated patients with or without T2DM were comparable to placebo and ezetimibe and no new safety risks were identified. Adverse event and serious adverse event data are summarised in Table 3.

\section{Discussion}

In this pooled analysis of data from three 12-week phase 3 randomised trials, we demonstrate that treatment of patients with T2DM with evolocumab, a PCSK9 inhibitor, led to an approximately $60 \%$ reduction in LDL-C compared with placebo, similar to that achieved in patients without T2DM. Furthermore, we demonstrate that reductions in LDL-C on evolocumab therapy were similar in patients with T2DM regardless of the presence or absence of cardiovascular disease, baseline levels of eGFR and $\mathrm{HbA}_{1 c}$, and the use or lack of use of insulin. We also demonstrate broadly similar and notable reductions in other lipid parameters in patients with (non-HDL-C [55\%], triglycerides [23\%], Lp(a) [31\%]) and without (non-HDL-C [58\%], triglycerides [17\%], Lp(a) [29\%]) T2DM compared with placebo. The analyses showed no particular safety concerns in patients with T2DM. Collectively, these data lead us to conclude that evolocumab has promising efficacy and safety in patients with T2DM. 
The potential clinical relevance of these findings merits discussion. Despite the introduction of interventions which have considerably reduced cardiovascular risk, T2DM continues to be associated with significantly elevated cardiovascular risk in comparison with people without T2DM, on average approximately two-fold. ${ }^{14}$ It is estimated that a patient aged 60 years with T2DM and a history of prior myocardial infarction or stroke loses 12 years of life expectancy on average ${ }^{15}$ highlighting the need for effective interventions for both the primary and secondary prevention of cardiovascular events. In terms of pharmaceutical interventions, reductions in vascular risk in T2DM appear to be best achieved by lipid and blood pressurelowering. ${ }^{16}$ Consequently, major national guidelines recommend relevant therapies to a substantial proportion of those with T2DM without cardiovascular disease. ${ }^{17}$ Data from an ongoing evolocumab outcomes trial, FOURIER (NCT01764633), will provide insight on the effects of evolocumab on cardiovascular outcomes.

Pooled data from multiple statin trials have confirmed the ability of these LDL-C lowering agents to reduce cardiovascular risk compared with placebo. ${ }^{3}$ In addition, more intensive LDL-C lowering therapy, whether by intensification of statin therapy or the addition of ezetimibe, yields further cardiovascular benefit. In individual participant data meta-analyses of intensive vs. moderate dose statin therapy, major cardiovascular events were reduced by $24 \%$ per one $\mathrm{mmol} / \mathrm{L}$ reduction in LDL-C (web figure 9 of reference ${ }^{18}$ ). And in the IMPROVE-IT trial, subgroup analysis of the 4,933 patients with diabetes showed that the $0 \cdot 4 \mathrm{mmol} / \mathrm{L}$ reduction in LDL-C achieved on ezetimibe led to a further $14 \%$ reduction in major cardiovascular events. ${ }^{4}$ This strongly supports the hypothesis that further LDL-C lowering achieved on top of baseline statin therapy may yield cardiovascular benefit in the absence of any off-target deleterious effects. 
Evidence from Mendelian Randomisation studies implicates Lp(a) as a cause of cardiovascular disease. The data presented herein confirmed that evolocumab therapy led to a $31 \%$ reduction in lipoprotein(a) in patients with T2DM, a potentially beneficial effect that is not observed with statin therapy for a lipoprotein which is causally linked to cardiovascular disease in those with and without diabetes ${ }^{19}$. In addition, it is recognised that not only LDL but also other triglyceride-rich apolipoprotein B-carrying lipoproteins like VLDL, which is known to be elevated in T2DM, are atherogenic. The 55\% observed reduction in non-HDL cholesterol is therefore noteworthy. However, the AIM-HIGH trial found no additional cardiovascular event reduction from salutary changes in lipids and lipoproteins other than LDL-C ${ }^{20}$. Therefore, whether changes in other lipids or lipoproteins in addition to LDL-C lowering will result in further cardiovascular event reduction remains to be determined. In addition, a study investigating the effect of PCSK9 inhibition on postprandial lipid metabolism would be of interest.

Major ongoing trials of PCSK9 inhibitors will provide conclusive data to inform the use of these agents in patients with T2DM. If these agents provide benefit beyond what is achieved with maximal statin therapy, patients with T2DM who could be considered for PCSK9 inhibitor therapy are likely to include those with established cardiovascular disease or at sufficiently elevated cardiovascular risk who have previously developed myopathy or rhabdomyolysis on statin therapy. In addition, patients who experience additional cardiovascular events despite maximal statin therapy may warrant consideration. Of interest, despite the proven benefits of statin therapy, rates of statin use in recent cardiovascular outcome trials in patients with T2DM and cardiovascular disease have only been approximately $80 \% .^{21}$ Why one in five patients with diabetes was not on a statin is currently unclear, but this group probably includes not only a proportion who reported intolerance to 
statins but also some patients who were undertreated. ${ }^{22,23}$ This level of statin use in patients with established cardiovascular disease is also concordant with recent data from the EUROASPIRE III study ${ }^{22}$ and with recently reported CVD trials. ${ }^{24}$ The major ongoing cardiovascular outcomes trials with PCSK9 inhibitors will reveal whether these marked reductions in LDL-C will lead to corresponding further reductions in cardiovascular event rates.

The limitations of the present study include its post-hoc nature and its relatively short duration of follow-up, namely 12 weeks. We were therefore unable to assess effects on major cardiovascular events. LDL-C was calculated by the Friedewald equation or through preparative ultracentrifugation when relevant. In addition, our results may not necessarily be generalizable to all patients with diabetes as they were selected on the basis of their lipid profiles and cardiovascular risk. The potential effect of substantial LDL-c lowering on newonset diabetes and related traits is the subject on ongoing work. We have also only presented data from the relatively short 12 week studies but the lipid-modifying effects of evolocumab have been consistent over time in longer trials. The strengths of this study include the use of randomised trial data, the numbers of patients with and without diabetes in each arm, and the ability to test the efficacy of evolocumab on key lipid parameters and across a range of T2DM patients with differing characteristics.

In summary, we demonstrate that treatment with the PCSK9 inhibitor, evolocumab, yields substantial reductions in atherogenic lipoproteins in patients with T2DM with a range of characteristics, similar to what is achieved in those without T2DM. 
Acknowledgements: The authors acknowledge Charlotte White of Amgen Inc. for providing statistical and programming support, and Annalise M. Nawrocki, PhD, of Amgen Inc. and Katherine Hsu, PharmD, on behalf of Amgen Inc. for providing editorial assistance.

Funding: This study was funded by Amgen, Inc.

Declarations of interest: NS reports consulting fees for Amgen, Sanofi, Astrazeneca, Merck, Eli Lilly and Boehringer Ingelheim and grant support through his institution from Astrazeneca and Amgen. DP reports consulting for Sanofi during previous employment. JGR reports receiving consulting fees from Amgen, Genentech/Roche, Merck, Pfizer, and Regeneron Pharmaceuticals/Sanofi and grant support through her institution from Amarin, Amgen, AstraZeneca, Daiichi-Sankyo, Eisai, Genentech/Roche, GlaxoSmithKline, Merck, Pfizer, Regeneron Pharmaceuticals/Sanofi, and Zinfandel Pharmaceuticals/Takeda. SD, ME, RS, and SMW are employees of Amgen and own Amgen stock/stock options. FJR reports grants to the University of Witwatersrand, has received consulting fees from Amgen and Sanofi related to PCSK9 inhibitors and from Genzyme related to apolipoprotein B inhibitors, and has received personal fees and non-financial support from AstraZeneca, Pfizer, and Merck.

Author contributions: NS and DP had the idea for and designed the study, collected and interpreted data, wrote the first draft of the manuscript, and revised later drafts of the manuscript. JGR and FJR designed the study, collected, and interpreted data, and critically revised later drafts of the article. SD, RS and SMW had the idea for and designed the study, collected and interpreted data, revised later drafts of the article, and obtained funding for the study. ME performed statistical analyses and critically revised later drafts of the article. 


\section{REFERENCES}

1. Seshasai SR KS, Thompson A, Di AE, Gao P, Sarwar N, et al. Diabetes mellitus, fasting glucose, and risk of cause-specific death. N Engl J Med 2011; 364(9): 829-41. 2. Colhoun HM BD, Durrington PN, Hitman GA, Neil HA, Livingstone SJ et al. Primary prevention of cardiovascular disease with atorvastatin in type 2 diabetes in the Collaborative Atorvastatin Diabetes Study (CARDS): multicentre randomised placebocontrolled trial. Lancet 2004; 317(9607): 117-25.

3. Kearney PM BL, Collins R, Keech A, Simes J, Peto R et al. Efficacy of cholesterollowering therapy in 18,686 people with diabetes in 14 randomised trials of statins: a metaanalysis. Lancet 2008; 371(9607): 117-25.

4. Cannon CP BM, Giugliano RP, McCagg A, White JA, Theroux P et al. Ezetimibe Added to Statin Therapy after Acute Coronary Syndromes. N Engl J Med 2015; 372(25): 2387-97.

5. Di AE, Kaptoge S, Wormser D, Willeit P, Butterworth AS, Bansal N et al. Association of Cardiometabolic Multimorbidity With Mortality. JAMA 2015; 314(1): 52-60. 6. Emerging Risk Factors C, Di Angelantonio E, Sarwar N, et al. Major lipids, apolipoproteins, and risk of vascular disease. JAMA 2009; 302(18): 1993-2000.

7. Krauss RM. Lipids and lipoproteins in patients with type 2 diabetes. Diabetes Care 2004; 27(6): 1496-504.

8. Lambert G, Sjouke B, Choque B, Kastelein JJ, Hovingh GK. The PCSK9 decade. $J$ Lipid Res 2012; 53(12): 2515-24.

9. Li C, Lin L, Zhang W, Zhou L, Wang H, Luo X et al. Efficiency and Safety of Proprotein Convertase Subtilisin/Kexin 9 Monoclonal Antibody on Hypercholesterolemia: A Meta-Analysis of 20 Randomized Controlled Trials. J American Heart Associ 2015; 4(6): e001937.

10. Robinson JG NB, Rogers WJ, Fialkow J, Neutel JM, Ramstad D et al. Effect of evolocumab or ezetimibe added to moderate- or high-intensity statin therapy on LDL-C lowering in patients with hypercholesterolemia: the LAPLACE-2 randomized clinical trial. JAMA 2014; 311(18): 1870-82.

11. Raal FJ SE, Dufour R, Turner T, Civeira F, Burgess L et al. . PCSK9 inhibition with evolocumab (AMG 145) in heterozygous familial hypercholesterolaemia (RUTHERFORD2): a randomised, double-blind, placebo-controlled trial. Lancet 2015; 335(9965): 331-40. 12. Stroes E CD, Sullivan D, Civeira F, Rosenson RS, Watts GF et al. . Anti-PCSK9 antibody effectively lowers cholesterol in patients with statin intolerance: the GAUSS-2 randomized, placebo-controlled phase 3 clinical trial of evolocumab. J Am Coll Cardiol 2014; 63(23): 2541-8.

13. Koren MJ, Lundqvist P, Bolognese M, et al. Anti-PCSK9 monotherapy for hypercholesterolemia: the MENDEL-2 randomized, controlled phase III clinical trial of evolocumab. J Am Coll Cardiol 2014; 63(23): 2531-40.

14. Emerging Risk Factors C, Sarwar N, Gao P, et al. Diabetes mellitus, fasting blood glucose concentration, and risk of vascular disease: a collaborative meta-analysis of 102 prospective studies. Lancet 2010; 375(9733): 2215-22.

15. Emerging Risk Factors C, Di Angelantonio E, Kaptoge S, et al. Association of Cardiometabolic Multimorbidity With Mortality. JAMA 2015; 314(1): 52-60.

16. Ray KK, Seshasai SR, Wijesuriya S, et al. Effect of intensive control of glucose on cardiovascular outcomes and death in patients with diabetes mellitus: a meta-analysis of randomised controlled trials. Lancet 2009; 373(9677): 1765-72.

17. Standards of medical care in diabetes--2015: summary of revisions. Diabetes Care 2015; 38 Suppl: S4. 
18. Cholesterol Treatment Trialists C, Baigent C, Blackwell L, et al. Efficacy and safety of more intensive lowering of LDL cholesterol: a meta-analysis of data from 170,000 participants in 26 randomised trials. Lancet 2010; 376(9753): 1670-81.

19. Clarke R, Peden JF, Hopewell JC, et al. Genetic variants associated with Lp(a) lipoprotein level and coronary disease. N Engl J Med 2009; 361(26): 2518-28.

20. Investigators A-H, Boden WE, Probstfield JL, et al. Niacin in patients with low HDL cholesterol levels receiving intensive statin therapy. N Engl J Med 2011; 365(24): 2255-67.

21. Scirica BM, Bhatt DL, Braunwald E, et al. Saxagliptin and cardiovascular outcomes in patients with type 2 diabetes mellitus. N Engl J Med 2013; 369(14): 1317-26.

22. Gyberg V, Kotseva K, Dallongeville J, et al. Does pharmacologic treatment in patients with established coronary artery disease and diabetes fulfil guideline recommended targets? A report from the EUROASPIRE III cross-sectional study. Eur J Prev Cardiol 2015; 22(6): 753-61.

23. Quek RG, Fox KM, Wang L, Li L, Gandra SR, Wong ND. Lipid-lowering treatment patterns among patients with type 2 diabetes mellitus with high cardiovascular disease risk. BMJ open diabetes research \& care $2015 ; \mathbf{3}(1)$ : e000132.

24. Zinman B, Wanner C, Lachin JM, et al. Empagliflozin, Cardiovascular Outcomes, and Mortality in Type 2 Diabetes. N Engl J Med 2015. 


\section{Figure Legends:}

Figure 1. Study design

Abbreviations: LAPLACE: LDL-C Assessment with PCSK9 Monoclonal Antibody Inhibition Combined With Statin Therapy); RUTHERFORD: Reduction of LDL-C With PCSK9 Inhibition in Heterozygous Familial Hypercholesterolemia Disorder Study; GAUSS: Goal Achievement after Utilizing an Anti-PCSK9 Antibody in Statin Intolerant Subjects; HeFH: heterozygous familial hypercholesterolaemia; T2DM: type 2 diabetes mellitus

Figure 2. LDL-cholesterol (A), non-HDL-cholesterol (B), triglycerides (C) lipoprotein(a) (D) and HDL-cholesterol (E) percentage changes from baseline versus placebo or evolocumab at week at 12 in patients with and without T2DM.

Footnote: Error bars indicate standard error of the mean. For all treatment differences except for triglycerides (evolocumab versus ezetimibe), $P<0.001$ for both evolocumab versus placebo and evolocumab versus ezetimibe.

Abbreviations: Lp(a): lipoprotein(a); T2DM: type 2 diabetes mellitus; SE: standard error

Figure 3. Reductions in LDL-cholesterol in diabetes subgroups.

Footnote: Error bars indicate 95\% confidence intervals.

Abbreviations: eGFR: estimated glomerular filtration rate; EvoMab: evolocumab; HbA1c: haemoglobin A1c 
Table 1. Baseline characteristics of participants in three evolocumab trials

\begin{tabular}{|c|c|c|c|c|c|c|c|c|}
\hline & \multicolumn{2}{|c|}{ LAPLACE-2 } & \multicolumn{2}{|c|}{ RUTHERFORD-2 } & \multicolumn{2}{|c|}{ GAUSS-2 } & \multicolumn{2}{|c|}{ All Patients } \\
\hline & T2DM & No T2DM & T2DM & No T2DM & T2DM & No T2DM & T2DM & No T2DM \\
\hline $\mathbf{N}$ & 322 & 1574 & 28 & 301 & 63 & 244 & 413 & 2119 \\
\hline $\begin{array}{l}\text { Sex } \\
\text { Female }\end{array}$ & $\begin{array}{c}137 \\
(42 \cdot 5 \%)\end{array}$ & $\begin{array}{c}731 \\
(46 \cdot 4 \%)\end{array}$ & $\begin{array}{c}12 \\
(42.9 \%)\end{array}$ & $\begin{array}{c}127 \\
(42 \cdot 2 \%)\end{array}$ & $\begin{array}{c}35 \\
(55 \cdot 6 \%)\end{array}$ & $\begin{array}{c}106 \\
(43.4 \%)\end{array}$ & $\begin{array}{c}184 \\
(44 \cdot 6 \% \\
)\end{array}$ & $\begin{array}{c}964 \\
(45 \cdot 5 \%)\end{array}$ \\
\hline Age, years & $\begin{array}{l}61 \cdot 7 \\
(8 \cdot 4)\end{array}$ & $\begin{array}{c}59 \cdot 5 \\
(10 \cdot 2)\end{array}$ & $\begin{array}{l}54 \cdot 0 \\
(9 \cdot 6)\end{array}$ & $\begin{array}{c}50 \cdot 9 \\
(12 \cdot 8)\end{array}$ & $\begin{array}{l}62 \cdot 6 \\
(8 \cdot 8)\end{array}$ & $\begin{array}{c}61 \cdot .2 \\
(10 \cdot 0)\end{array}$ & $\begin{array}{l}61 \cdot .3 \\
(8 \cdot 7)\end{array}$ & $\begin{array}{c}58 \cdot 4 \\
(11 \cdot 0)\end{array}$ \\
\hline BMI, $\mathrm{kg} / \mathrm{m}^{2}$ & $\begin{array}{l}32 \cdot 2 \\
(6 \cdot 1)\end{array}$ & $\begin{array}{l}28 \cdot 9 \\
(5 \cdot 1)\end{array}$ & $\begin{array}{l}31 \cdot 3 \\
(4 \cdot 9)\end{array}$ & $\begin{array}{l}27 \cdot 6 \\
(4 \cdot 4)\end{array}$ & $\begin{array}{l}31 \cdot 3 \\
(6 \cdot 0)\end{array}$ & $\begin{array}{l}28 \cdot 2 \\
(4 \cdot 3)\end{array}$ & $\begin{array}{l}32 \cdot 0 \\
(6 \cdot 0)\end{array}$ & $28 \cdot 6(4 \cdot 9)$ \\
\hline SBP, mmHg & $\begin{array}{l}130 \cdot .0 \\
(14 \cdot 5)\end{array}$ & $\begin{array}{l}128 \cdot 3 \\
(14 \cdot 4)\end{array}$ & $\begin{array}{l}123 \cdot .6 \\
(15 \cdot 0)\end{array}$ & $\begin{array}{l}125 \cdot .9 \\
(13 \cdot 5)\end{array}$ & $\begin{array}{l}134 \cdot 8 \\
(15 \cdot 9)\end{array}$ & $\begin{array}{l}132 \cdot .3 \\
(14 \cdot 8)\end{array}$ & $\begin{array}{l}130 \cdot 3 \\
(14 \cdot 9)\end{array}$ & $\begin{array}{l}128 \cdot 4 \\
(14 \cdot 4)\end{array}$ \\
\hline DBP, I & $\begin{array}{l}78 \cdot 9 \\
(9 \cdot 5)\end{array}$ & $\begin{array}{l}78 \cdot 6 \\
(8 \cdot 9)\end{array}$ & $\begin{array}{c}74.9 \\
(11 \cdot 3)\end{array}$ & $\begin{array}{l}77 \cdot 5 \\
(9 \cdot 4)\end{array}$ & $\begin{array}{l}78 \cdot 3 \\
(8 \cdot 7)\end{array}$ & $\begin{array}{l}79 \cdot 0 \\
(9 \cdot 6)\end{array}$ & $\begin{array}{l}78 \cdot 6 \\
(9 \cdot 5)\end{array}$ & $78 \cdot 5(9 \cdot 1)$ \\
\hline Hype & $\begin{array}{c}269 \\
(83 \cdot 5 \%)\end{array}$ & $\begin{array}{c}815 \\
(51 \cdot 8 \%)\end{array}$ & $\begin{array}{c}17 \\
(60.7 \%)\end{array}$ & $\begin{array}{c}90 \\
(29.9 \%)\end{array}$ & $\begin{array}{c}56 \\
(88.9 \%)\end{array}$ & $\begin{array}{c}125 \\
(51 \cdot 2 \%)\end{array}$ & $\begin{array}{c}342 \\
(82 \cdot 8 \% \\
)\end{array}$ & $\begin{array}{c}1030 \\
(48 \cdot 6 \%)\end{array}$ \\
\hline Smol & $\begin{array}{c}55 \\
(17 \cdot 1 \%)\end{array}$ & $\begin{array}{c}236 \\
(15 \cdot 0 \%)\end{array}$ & $\begin{array}{c}6 \\
(21 \cdot 4 \%)\end{array}$ & $\begin{array}{c}46 \\
(15 \cdot 3 \%)\end{array}$ & $\begin{array}{c}7 \\
(11 \cdot 1 \%)\end{array}$ & $\begin{array}{c}17 \\
(7.0 \%)\end{array}$ & $\begin{array}{c}68 \\
(16 \cdot 5 \% \\
)\end{array}$ & $\begin{array}{c}299 \\
(14 \cdot 1 \%)\end{array}$ \\
\hline CAD & $\begin{array}{c}101 \\
(31.4 \%)\end{array}$ & $\begin{array}{c}326 \\
(20 \cdot 7 \%)\end{array}$ & $\begin{array}{c}16 \\
(57 \cdot 1 \%)\end{array}$ & $\begin{array}{c}87 \\
(28.9 \%)\end{array}$ & $\begin{array}{c}14 \\
(22 \cdot 2 \%)\end{array}$ & $\begin{array}{c}76 \\
(31 \cdot 1 \%)\end{array}$ & $\begin{array}{c}131 \\
(31 \cdot 7 \% \\
)\end{array}$ & $\begin{array}{c}489 \\
(23 \cdot 1 \%)\end{array}$ \\
\hline HbA1c, \% & $\begin{array}{c}6 \cdot 5 \\
(0 \cdot 9)\end{array}$ & $\begin{array}{c}5 \cdot 5 \\
(0 \cdot 3)\end{array}$ & $\begin{array}{c}6 \cdot 8 \\
(0 \cdot 8)\end{array}$ & $\begin{array}{c}5 \cdot 4 \\
(0 \cdot 4)\end{array}$ & $\begin{array}{c}6 \cdot 6 \\
(0 \cdot 8)\end{array}$ & $\begin{array}{c}5 \cdot 5 \\
(0 \cdot 3)\end{array}$ & $\begin{array}{c}6 \cdot 6 \\
(0 \cdot 9)\end{array}$ & $\begin{array}{c}5 \cdot 5 \\
(0 \cdot 3)\end{array}$ \\
\hline $\begin{array}{l}\text { HbA1c, } \\
\mathrm{mmol} / \mathrm{mol}\end{array}$ & $\begin{array}{l}47.5 \\
(9 \cdot 8)\end{array}$ & $\begin{array}{l}36.6 \\
(3 \cdot 3)\end{array}$ & $\begin{array}{l}50.8 \\
(8 \cdot 7)\end{array}$ & $\begin{array}{l}35.5 \\
(4 \cdot 4)\end{array}$ & $\begin{array}{l}48.6 \\
(8 \cdot 7)\end{array}$ & $\begin{array}{l}36.6 \\
(3 \cdot 3)\end{array}$ & $\begin{array}{l}48.6 \\
(9 \cdot 8)\end{array}$ & $\begin{array}{l}36.6 \\
(3 \cdot 3)\end{array}$ \\
\hline FPG, $n$ & $\begin{array}{c}7 \cdot 1 \\
(1 \cdot 9)\end{array}$ & $\begin{array}{c}5 \cdot 3 \\
(0 \cdot 6)\end{array}$ & $\begin{array}{c}7 \cdot 3 \\
(1 \cdot 8)\end{array}$ & $\begin{array}{c}5 \cdot 3 \\
(0 \cdot 6)\end{array}$ & $\begin{array}{c}7 \cdot 1 \\
(2 \cdot 2)\end{array}$ & $\begin{array}{c}5 \cdot 3 \\
(0 \cdot 6)\end{array}$ & $\begin{array}{c}7 \cdot 1 \\
(1 \cdot 9)\end{array}$ & $\begin{array}{c}5 \cdot 3 \\
(0 \cdot 6)\end{array}$ \\
\hline PCSK9, & $\begin{array}{c}4.8 \\
(1.5)\end{array}$ & $\begin{array}{c}4.9 \\
(1.6)\end{array}$ & $\begin{array}{c}7.0 \\
(1.8)\end{array}$ & $\begin{array}{c}6.1 \\
(1.9)\end{array}$ & $\begin{array}{c}4.2 \\
(1.1)\end{array}$ & $\begin{array}{c}3.9 \\
(1.4)\end{array}$ & $\begin{array}{c}4.9 \\
(1.6)\end{array}$ & $\begin{array}{l}5 \cdot 0 \\
(1 \cdot 7)\end{array}$ \\
\hline $\begin{array}{l}\text { LDL-cholesterol } \\
(\mathrm{mmol} / \mathrm{L})\end{array}$ & $\begin{array}{c}2 \cdot 5 \\
(0 \cdot 8)\end{array}$ & $\begin{array}{c}2 \cdot 9 \\
(1 \cdot 1)\end{array}$ & $\begin{array}{c}4 \cdot 1 \\
(1 \cdot 6)\end{array}$ & $\begin{array}{c}4 \cdot 0 \\
(1 \cdot 1)\end{array}$ & $\begin{array}{c}4 \cdot 3 \\
(1 \cdot 1)\end{array}$ & $\begin{array}{c}5 \cdot 2 \\
(1 \cdot 6)\end{array}$ & $\begin{array}{c}2 \cdot 9 \\
(1 \cdot 2)\end{array}$ & $\begin{array}{l}3 \cdot 3 \\
(1 \cdot 4)\end{array}$ \\
\hline $\begin{array}{l}\text { Non-HDL- } \\
\text { cholesterol } \\
(\mathrm{mmol} / \mathrm{L})\end{array}$ & $\begin{array}{c}3 \cdot 3 \\
(0 \cdot 9)\end{array}$ & $\begin{array}{c}3 \cdot 6 \\
(1 \cdot 2)\end{array}$ & $\begin{array}{c}4 \cdot 8 \\
(1 \cdot 8)\end{array}$ & $\begin{array}{c}4 \cdot 7 \\
(1 \cdot 2)\end{array}$ & $\begin{array}{c}5 \cdot 4 \\
(1 \cdot 3)\end{array}$ & $\begin{array}{l}6 \cdot 0 \\
(1 \cdot 6)\end{array}$ & $\begin{array}{c}3 \cdot 8 \\
(1 \cdot 3)\end{array}$ & $\begin{array}{l}4 \cdot 0 \\
(1 \cdot 5)\end{array}$ \\
\hline $\begin{array}{l}\text { Total cholesterol } \\
(\mathrm{mmol} / \mathrm{L})\end{array}$ & $\begin{array}{l}4 \cdot 5 \\
(0 \cdot 9)\end{array}$ & $\begin{array}{c}5 \cdot 0 \\
(1 \cdot 2)\end{array}$ & $\begin{array}{c}5 \cdot 9 \\
(1 \cdot 8)\end{array}$ & $\begin{array}{c}6 \cdot 0 \\
(1 \cdot 2)\end{array}$ & $\begin{array}{c}6 \cdot 6 \\
(1 \cdot 2)\end{array}$ & $\begin{array}{c}7 \cdot 4 \\
(1 \cdot 6)\end{array}$ & $\begin{array}{c}4 \cdot 9 \\
(1 \cdot 3)\end{array}$ & $\begin{array}{c}5 \cdot 4 \\
(1 \cdot 5)\end{array}$ \\
\hline $\begin{array}{l}\text { Triglycerides } \\
(\mathrm{mmol} / \mathrm{L})^{*}\end{array}$ & $\begin{array}{c}1 \cdot 6 \\
(1 \cdot 2,2 \cdot 3)\end{array}$ & $\begin{array}{c}1 \cdot 3 \\
(1.0,1 \cdot 7)\end{array}$ & $\begin{array}{l}1.5 \\
(1 \cdot 2, \\
1.9)\end{array}$ & $\begin{array}{c}1 \cdot 2 \\
(0 \cdot 9,1 \cdot 7)\end{array}$ & $\begin{array}{c}2 \cdot 2 \\
(1 \cdot 6, \\
3 \cdot 0)\end{array}$ & $\begin{array}{c}1 \cdot 7 \\
(1 \cdot 2,2 \cdot 3)\end{array}$ & $\begin{array}{l}1 \cdot 7 \\
(1 \cdot 2, \\
2 \cdot 3)\end{array}$ & $\begin{array}{c}1 \cdot 3 \\
(1 \cdot 0,1 \cdot 8)\end{array}$ \\
\hline $\begin{array}{l}\text { Lipoprotein(a) } \\
(\mathbf{n m o l} / \mathbf{L})^{*}\end{array}$ & $\begin{array}{c}34 \\
(11,147)\end{array}$ & $\begin{array}{c}34 \\
(11,165)\end{array}$ & $\begin{array}{l}76 \\
(25, \\
211)\end{array}$ & $\begin{array}{c}65 \\
(25,197)\end{array}$ & $\begin{array}{c}29 \\
(9,98)\end{array}$ & $\begin{array}{c}32 \\
(11,134)\end{array}$ & $\begin{array}{l}35 \\
(12, \\
147)\end{array}$ & $\begin{array}{c}38 \\
(12,168)\end{array}$ \\
\hline $\begin{array}{l}\text { HDL-cholesterol } \\
(\mathrm{mmol} / \mathrm{L})\end{array}$ & $\begin{array}{c}1 \cdot 2 \\
(0 \cdot 3)\end{array}$ & $\begin{array}{c}1 \cdot 4 \\
(0 \cdot 4)\end{array}$ & $\begin{array}{c}1 \cdot 1 \\
(0 \cdot 3)\end{array}$ & $\begin{array}{c}1 \cdot 4 \\
(0 \cdot 4)\end{array}$ & $\begin{array}{c}1 \cdot 2 \\
(0 \cdot 3)\end{array}$ & $\begin{array}{c}1 \cdot 4 \\
(0 \cdot 4)\end{array}$ & $\begin{array}{c}1 \cdot 2 \\
(0 \cdot 3)\end{array}$ & $\begin{array}{c}1 \cdot 4 \\
(0 \cdot 4)\end{array}$ \\
\hline
\end{tabular}

Data presented as mean (SD) or $\mathrm{n}(\%)$ unless otherwise indicated

*median (IQR)

Abbreviations: CAD, coronary artery disease; DBP, diastolic blood pressure; FPG, fasting plasma 
glucose; T2DM: type 2 diabetes mellitus; HDL, high-density lipoprotein; LDL, low-density lipoprotein; PCSK9, proprotein convertase subtilisin/kexin type 9; SBP, systolic blood pressure 
Table 2. Percentage change in lipid parameters in evolocumab- vs placebo- or ezetimibetreated patients with and without diabetes at week 12

\begin{tabular}{|c|c|c|c|c|c|c|}
\hline & \multicolumn{3}{|c|}{ Evolocumab vs Placebo ${ }^{\mathrm{a}}$} & \multicolumn{3}{|c|}{ Evolocumab vs Ezetimibe $^{\mathrm{b}}$} \\
\hline & T2DM & No T2DM & $\begin{array}{c}\mathrm{P} \text { for } \\
\text { interaction }\end{array}$ & T2DM & No T2DM & $\begin{array}{c}\mathrm{P} \text { for } \\
\text { interaction }\end{array}$ \\
\hline $\begin{array}{l}\text { n (EvoMab / } \\
\text { Pbo or Eze) }\end{array}$ & $210 / 94$ & $1127 / 573$ & - & $114 / 73$ & $530 / 250$ & - \\
\hline $\begin{array}{l}\text { LDL- } \\
\text { cholesterol }\end{array}$ & $\begin{array}{c}-60 \\
(-69,-51) \\
\underline{\mathrm{P}<0} \cdot \underline{001}\end{array}$ & $\begin{array}{c}-66 \\
(-70,-62) \\
\underline{\mathrm{P}<0} \cdot \underline{001}\end{array}$ & $0 \cdot 27$ & $\begin{array}{c}-39 \\
(-47,-32) \\
\underline{\mathrm{P}<0} \cdot \underline{001}\end{array}$ & $\begin{array}{c}-40 \\
(-45,-36) \\
\underline{\mathrm{P}<0} \cdot \underline{001}\end{array}$ & 0.79 \\
\hline $\begin{array}{l}\text { Non-HDL- } \\
\text { cholesterol }\end{array}$ & $\begin{array}{c}-55 \\
(-63,-47) \\
\underline{\mathrm{P}<0} \cdot \underline{001}\end{array}$ & $\begin{array}{c}-58 \\
(-61,-55) \\
\underline{\mathrm{P}<0} \cdot \underline{001}\end{array}$ & $0 \cdot 42$ & $\begin{array}{c}-34 \\
(-41,-26) \\
\underline{\mathrm{P}<0} \cdot \underline{001}\end{array}$ & $\begin{array}{c}-35 \\
(-40,-31) \\
\underline{\mathrm{P}<0} \cdot \underline{001}\end{array}$ & $0 \cdot 72$ \\
\hline $\begin{array}{l}\text { Total } \\
\text { cholesterol }\end{array}$ & $\begin{array}{c}-38 \\
(-44,-32) \\
\mathrm{P}<0.001 \\
\end{array}$ & $\begin{array}{c}-40 \\
(-42,-37) \\
\mathrm{P}<0.001 \\
\end{array}$ & $0 \cdot 57$ & $\begin{array}{c}-24 \\
(-31,-16) \\
\mathrm{P}<0.001 \\
\end{array}$ & $\begin{array}{c}-25 \\
(-27,-23) \\
\mathrm{P}<0.001 \\
\end{array}$ & $0 \cdot 76$ \\
\hline Triglycerides & $\begin{array}{c}-23 \\
(-34,-12) \\
\underline{\mathrm{P}<0.001}\end{array}$ & $\begin{array}{c}-17 \\
(-21,-14) \\
\underline{\mathrm{P}<0 .} .001\end{array}$ & $0 \cdot 34$ & $\begin{array}{c}-9 \\
(-23,5) \\
\underline{P=0} \cdot \underline{20}\end{array}$ & $\begin{array}{c}-3 \\
(-8,3) \\
\underline{\mathrm{P}=0} \cdot \underline{31}\end{array}$ & $0 \cdot 41$ \\
\hline Lipoprotein(a) & $\begin{array}{c}-31 \\
(-37,-25) \\
\underline{\mathrm{P}<0} \cdot \underline{001}\end{array}$ & $\begin{array}{c}-29 \\
(-32,-26) \\
\underline{\mathrm{P}<0} \cdot \underline{001}\end{array}$ & 0.54 & $\begin{array}{c}-26 \\
(-35,-16) \\
\underline{\mathrm{P}<0} \cdot \underline{001}\end{array}$ & $\begin{array}{c}-30 \\
(-36,-24) \\
\underline{\mathrm{P}<0} \cdot \underline{001}\end{array}$ & $0 \cdot 42$ \\
\hline $\begin{array}{l}\text { HDL } \\
\text { cholesterol }\end{array}$ & $\begin{array}{l}8(4,11) \\
\underline{\mathrm{P}<0} \cdot \underline{001}\end{array}$ & $\begin{array}{c}7(5,9) \\
\mathrm{P}<0.001 \\
\end{array}$ & $0 \cdot 66$ & $\begin{array}{l}8(4,13) \\
\underline{\mathrm{P}<0} \cdot \underline{001}\end{array}$ & $\begin{array}{c}6(3,9) \\
\underline{\mathrm{P}<0} \cdot \underline{001}\end{array}$ & 0.43 \\
\hline
\end{tabular}

Data presented are the random effects treatment difference $(95 \% \mathrm{CI})$ between evolocumab and control (placebo or ezetimibe), generated using the Dersimonian-Laird random effect estimator ${ }^{a}$ Combined patients from LAPLACE-2 and RUTHERFORD-2;

${ }^{\mathrm{b}}$ Combined patients from LAPLACE-2 (atorvastatin cohorts only) and GAUSS-2; 
Table 3. Safety of evolocumab in patients with and without T2DM

\begin{tabular}{|c|c|c|c|c|c|c|}
\hline & \multicolumn{3}{|c|}{ With T2DM* } & \multicolumn{3}{|c|}{ Without T2DM* } \\
\hline & Placebo & $\begin{array}{l}\text { Placebo + } \\
\text { Ezetimibe }\end{array}$ & Evolocumab & Placebo & $\begin{array}{l}\text { Placebo + } \\
\text { Ezetimibe }\end{array}$ & Evolocumab \\
\hline $\mathbf{n}$ & 94 & 73 & 246 & 573 & 250 & 1,296 \\
\hline All AEs & $32(34 \cdot 0)$ & $34(46 \cdot 6)$ & $100(40 \cdot 7)$ & $243(42 \cdot 4)$ & $129(51 \cdot 6)$ & $570(44 \cdot 0)$ \\
\hline $\begin{array}{l}\text { Injection site } \\
\text { reactions }\end{array}$ & $0(0 \cdot 0)$ & $2(2 \cdot 7)$ & $3(1 \cdot 2)$ & $12(2 \cdot 1)$ & $7(2 \cdot 8)$ & $32(2 \cdot 5)$ \\
\hline Myalgia & $1(1 \cdot 1)$ & $3(4 \cdot 1)$ & $1(0 \cdot 4)$ & $10(1.7)$ & $19(7 \cdot 6)$ & $33(2 \cdot 5)$ \\
\hline Elevated CK & $0(0 \cdot 0)$ & $0(0 \cdot 0)$ & $1(0 \cdot 4)$ & $3(0 \cdot 5)$ & $1(0 \cdot 4)$ & $5(0 \cdot 4)$ \\
\hline Grade $\geq 2$ & $15(16 \cdot 0)$ & $14(19 \cdot 2)$ & $42(17 \cdot 1)$ & $100(17 \cdot 5)$ & $59(23 \cdot 6)$ & $210(16 \cdot 2)$ \\
\hline Grade $\geq 3$ & $6(6 \cdot 4)$ & $2(2 \cdot 7)$ & $8(3 \cdot 3)$ & $21(3 \cdot 7)$ & $7(2 \cdot 8)$ & $34(2 \cdot 6)$ \\
\hline Grade $\geq 4$ & $2(2 \cdot 1)$ & $0(0 \cdot 0)$ & $1(0 \cdot 4)$ & $3(0 \cdot 5)$ & $0(0 \cdot 0)$ & $7(0 \cdot 5)$ \\
\hline Serious AEs & $4(4 \cdot 3)$ & $3(4 \cdot 1)$ & $5(2 \cdot 0)$ & $14(2 \cdot 4)$ & $3(1 \cdot 2)$ & $31(2 \cdot 4)$ \\
\hline $\begin{array}{l}\text { Leading to } \\
\text { discontinuation }\end{array}$ & $0(0 \cdot 0)$ & $2(2 \cdot 7)$ & $1(0 \cdot 4)$ & $9(1 \cdot 6)$ & $6(2 \cdot 4)$ & $22(1 \cdot 7)$ \\
\hline $\begin{array}{l}\text { All-cause } \\
\text { mortality }\end{array}$ & $0(0 \cdot 0)$ & $0(0 \cdot 0)$ & $0(0 \cdot 0)$ & $1(0 \cdot 2)$ & $0(0 \cdot 0)$ & $0(0 \cdot 0)$ \\
\hline
\end{tabular}

Data presented as $\mathrm{n}(\%)$

Classification of AEs: Grade $2=$ moderate (discomfort enough to cause interference with usual activity); Grade $3=$ severe (incapacitating with inability to work or do usual activity); Grade $4=$ lifethreatening (refers to event in which the patient was, in the view of the investigator, at risk of death at the time of the event)

*Patients could also be receiving stable background statin therapy.

Abbreviations: T2DM: type 2 diabetes mellitus, AE: adverse event; CK: creatine kinase 
Supplementary Material: Lipid-Lowering Efficacy of the PCSK9 Inhibitor Evolocumab (AMG 145) in Patients With Type 2 Diabetes Mellitus

Supplementary Figure 1. PRISMA flow diagram for identification of relevant trials

Supplementary Table 1. Analysis of Week 12 Percent Change from Baseline in Lipids Compared with Placebo/Ezetimibe, Split by Statin Cohort and Diabetes Status

Supplementary Table 2. Percentage change in LDL-cholesterol in evolocumab- vs placebo-treated patients at week 12 
Supplementary Figure 1. PRISMA flow diagram for identification of relevant trials

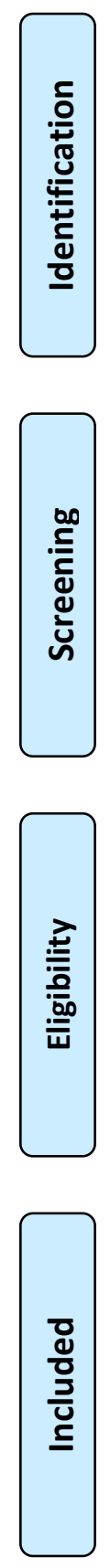

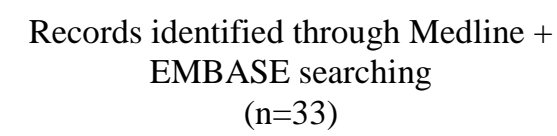

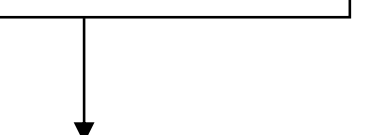

Records after duplicates removed $(\mathrm{n}=25)$
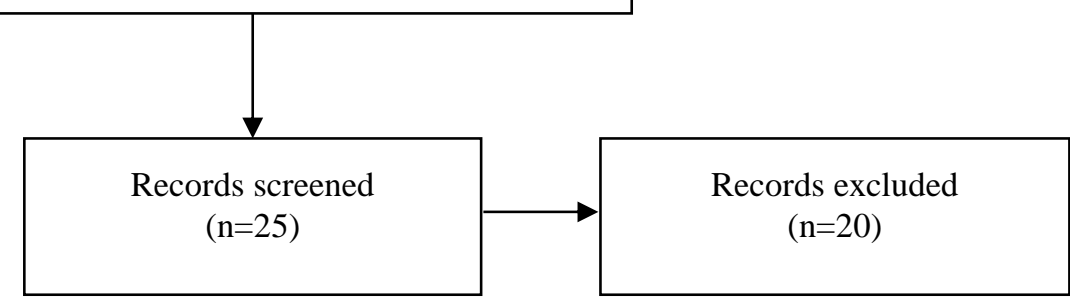

Full-text articles assessed for eligibility $(n=5)$

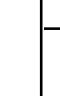

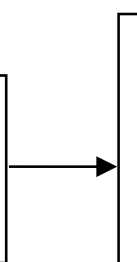

Studies included in qualitative synthesis $(n=3)$

Studies included in quantitative synthesis (metaanalysis $)$
$(n=3)$
Full-text articles excluded, with reasons $(n=2)$ :

TESLA B trial limited to patients with homozygous FH; MENDEL-2 trial excluded patients with diabetes 
Supplementary Table 1. Analysis of Week 12 Percentage change from baseline in Lipids compared with Placebo/Ezetimibe, split by statin cohort and diabetes status

\begin{tabular}{|c|c|c|c|c|c|c|c|c|c|c|c|c|c|c|c|c|}
\hline \multicolumn{17}{|c|}{ LDL-cholesterol } \\
\hline & \multicolumn{2}{|c|}{ RUTHERFORD-2 } & \multicolumn{3}{|c|}{ LAPLACE-2 Atorva 10mg cohort } & \multicolumn{3}{|c|}{$\begin{array}{l}\text { LAPLACE-2 Atorva 80mg } \\
\text { cohort }\end{array}$} & \multicolumn{2}{|c|}{$\begin{array}{l}\text { LAPLACE-2 Rosuva } \\
5 \mathrm{mg} \text { cohort }\end{array}$} & \multicolumn{2}{|c|}{$\begin{array}{l}\text { LAPLACE-2 Rosuva } \\
40 \mathrm{mg} \text { cohort }\end{array}$} & \multicolumn{2}{|c|}{$\begin{array}{l}\text { LAPLACE-2 Simva } \\
\text { 40mg cohort }\end{array}$} & \multicolumn{2}{|c|}{ GAUSS-2 } \\
\hline & Placebo & Evo & Placebo & Eze & Evo & Placebo & Eze & Evo & Placebo & Evo & Placebo & Evo & Placebo & Evo & Eze & Evo \\
\hline Diabetes & $\mathrm{N}=11$ & $\mathrm{~N}=17$ & $\mathrm{~N}=16$ & $\mathrm{~N}=17$ & $\mathrm{~N}=44$ & $\mathrm{~N}=18$ & $\mathrm{~N}=29$ & $\mathrm{~N}=34$ & $\mathrm{~N}=13$ & $\mathrm{~N}=41$ & $\mathrm{~N}=14$ & $\mathrm{~N}=35$ & $\mathrm{~N}=22$ & $\mathrm{~N}=39$ & $\mathrm{~N}=27$ & $\mathrm{~N}=36$ \\
\hline $\begin{array}{l}\text { LS mean } \\
(\mathrm{SE})\end{array}$ & $\begin{array}{c}-1 \cdot 9 \\
(10 \cdot 6)\end{array}$ & $\begin{array}{l}-44 \cdot 7 \\
(8 \cdot 2)\end{array}$ & $\begin{array}{l}13 \cdot 0 \\
(7 \cdot 8)\end{array}$ & $\begin{array}{l}-10 \cdot 5 \\
(7 \cdot 8)\end{array}$ & $\begin{array}{l}-55 \cdot 8 \\
(5 \cdot 1)\end{array}$ & $\begin{array}{l}-4 \cdot 0 \\
(7 \cdot 1)\end{array}$ & $\begin{array}{l}-24 \cdot 1 \\
(5 \cdot 5)\end{array}$ & $\begin{array}{r}-53 \cdot 2 \\
(5 \cdot 0)\end{array}$ & $\begin{array}{l}-2 \cdot 1 \\
(5 \cdot 3)\end{array}$ & $\begin{array}{l}-60 \cdot 5 \\
(3 \cdot 4)\end{array}$ & $\begin{array}{c}8 \cdot 7 \\
(12 \cdot 4)\end{array}$ & $\begin{array}{r}-48 \cdot 7 \\
(8 \cdot 7)\end{array}$ & $\begin{array}{l}16 \cdot 6 \\
(8 \cdot 5)\end{array}$ & $\begin{array}{l}-59 \cdot 7 \\
(7 \cdot 5)\end{array}$ & $\begin{array}{l}-12 \cdot 2 \\
(2 \cdot 9)\end{array}$ & $\begin{array}{l}-53 \cdot 2 \\
(2 \cdot 5)\end{array}$ \\
\hline $95 \% \mathrm{CI}$ & $\begin{array}{c}(-23 \cdot 6, \\
19 \cdot 8)\end{array}$ & $\begin{array}{l}(-61 \cdot 4, \\
-27 \cdot 9)\end{array}$ & $\begin{array}{l}(-2 \cdot 5, \\
28 \cdot 6)\end{array}$ & $\begin{array}{c}(-26 \cdot 0, \\
5 \cdot 0)\end{array}$ & $\begin{array}{l}(-65 \cdot 9 \\
-45 \cdot 6) \\
\end{array}$ & $\begin{array}{c}(-18 \cdot 1 \\
10 \cdot 2)\end{array}$ & $\begin{array}{l}(-35 \cdot 2, \\
-13 \cdot 1)\end{array}$ & $\begin{array}{l}(-63 \cdot 2, \\
-43 \cdot 2)\end{array}$ & $\begin{array}{c}(-12 \cdot 7 \\
8 \cdot 6)\end{array}$ & $\begin{array}{l}(-67 \cdot 2, \\
-53 \cdot 8)\end{array}$ & $\begin{array}{c}(-16 \cdot 4, \\
33 \cdot 8)\end{array}$ & $\begin{array}{l}(-66 \cdot 2, \\
-31 \cdot 2) \\
\end{array}$ & $\begin{array}{l}(-0 \cdot 4, \\
33 \cdot 6) \\
\end{array}$ & $\begin{array}{l}(-74 \cdot 7, \\
-44 \cdot 7)\end{array}$ & $\begin{array}{c}(-18 \cdot 0, \\
-6 \cdot 4)\end{array}$ & $\begin{array}{l}(-58 \cdot 2, \\
-48 \cdot 3)\end{array}$ \\
\hline $\begin{array}{c}\text { Non - } \\
\text { Diabetes }\end{array}$ & $\mathrm{N}=98$ & $\mathrm{~N}=203$ & $\mathrm{~N}=95$ & $\mathrm{~N}=94$ & $\mathrm{~N}=176$ & $\mathrm{~N}=92$ & $\mathrm{~N}=81$ & $\mathrm{~N}=185$ & $\mathrm{~N}=102$ & $\mathrm{~N}=187$ & $\mathrm{~N}=97$ & $\mathrm{~N}=188$ & $\mathrm{~N}=89$ & $\mathrm{~N}=188$ & $\mathrm{~N}=75$ & $\mathrm{~N}=169$ \\
\hline $\begin{array}{l}\text { LS mean } \\
(\mathrm{SE})\end{array}$ & $\begin{array}{c}2 \cdot 4 \\
(2 \cdot 1) \\
\end{array}$ & $\begin{array}{l}-59 \cdot 6 \\
(1 \cdot 4) \\
\end{array}$ & $\begin{array}{c}3 \cdot 7 \\
(1.8) \\
\end{array}$ & $\begin{array}{l}-21 \cdot 2 \\
(1.8) \\
\end{array}$ & $\begin{array}{l}-61 \cdot 5 \\
(1 \cdot 3) \\
\end{array}$ & $\begin{array}{l}16 \cdot 6 \\
(3 \cdot 2) \\
\end{array}$ & $\begin{aligned}-14 \cdot 7 \\
(3 \cdot 4) \\
\end{aligned}$ & $\begin{array}{l}-61 \cdot 7 \\
(2 \cdot 2) \\
\end{array}$ & $\begin{array}{c}7 \cdot 9 \\
(2 \cdot 1) \\
\end{array}$ & $\begin{array}{l}-59 \cdot 4 \\
(1 \cdot 6) \\
\end{array}$ & $\begin{array}{c}5 \cdot 5 \\
(2 \cdot 8) \\
\end{array}$ & $\begin{array}{l}-57 \cdot 2 \\
(2 \cdot 0) \\
\end{array}$ & $\begin{array}{c}2 \cdot 2 \\
(3 \cdot 0) \\
\end{array}$ & $\begin{array}{l}-60 \cdot 4 \\
(2 \cdot 4) \\
\end{array}$ & $\begin{aligned}-17 \cdot 5 \\
(1.9) \\
\end{aligned}$ & $\begin{array}{l}-54 \cdot 4 \\
(1 \cdot 4) \\
\end{array}$ \\
\hline $95 \% \mathrm{CI}$ & $\begin{array}{c}(-1 \cdot 6 \\
6 \cdot 5) \\
\end{array}$ & $\begin{array}{l}(-62 \cdot 4, \\
-56 \cdot 8) \\
\end{array}$ & $\begin{array}{l}(0 \cdot 2, \\
7 \cdot 2) \\
\end{array}$ & $\begin{array}{l}(-24 \cdot 8, \\
-17 \cdot 7) \\
\end{array}$ & $\begin{array}{l}(-64 \cdot 0, \\
-58 \cdot 9) \\
\end{array}$ & $\begin{array}{l}(10 \cdot 3, \\
23 \cdot 0) \\
\end{array}$ & $\begin{array}{c}(-21 \cdot 3, \\
-8 \cdot 0) \\
\end{array}$ & $\begin{array}{l}(-66 \cdot 1 \\
-57 \cdot 3) \\
\end{array}$ & $\begin{array}{l}3 \cdot 9, \\
12 \cdot 0) \\
\end{array}$ & $\begin{array}{l}(-62 \cdot 4, \\
-56 \cdot 3) \\
\end{array}$ & $\begin{array}{l}(0 \cdot 1 \\
11 \cdot 0) \\
\end{array}$ & $\begin{array}{l}(-61 \cdot 0 \\
-53 \cdot 3) \\
\end{array}$ & $\begin{array}{c}(-3 \cdot 7, \\
8 \cdot 1) \\
\end{array}$ & $\begin{array}{l}(-65 \cdot 1, \\
-55 \cdot 7) \\
\end{array}$ & $\begin{array}{l}(-21 \cdot 3, \\
-13 \cdot 7) \\
\end{array}$ & $\begin{array}{l}(-57 \cdot 2, \\
-51 \cdot 7) \\
\end{array}$ \\
\hline \multicolumn{17}{|c|}{ Non-HDL-cholesterol } \\
\hline & \multicolumn{2}{|c|}{ RUTHERFORD-2 } & \multicolumn{3}{|c|}{ LAPLACE-2 Atorva 10mg cohort } & \multicolumn{3}{|c|}{$\begin{array}{l}\text { LAPLACE-2 Atorva 80mg } \\
\text { cohort }\end{array}$} & \multicolumn{2}{|c|}{$\begin{array}{l}\text { LAPLACE-2 Rosuva } \\
5 \mathrm{mg} \text { cohort }\end{array}$} & \multicolumn{2}{|c|}{$\begin{array}{l}\text { LAPLACE-2 Rosuva } \\
\text { 40mg cohort }\end{array}$} & \multicolumn{2}{|c|}{$\begin{array}{l}\text { LAPLACE-2 Simva } \\
\text { 40mg cohort }\end{array}$} & \multicolumn{2}{|c|}{ GAUSS-2 } \\
\hline & Placebo & Evo & Placebo & Eze & Evo & Placebo & Eze & Evo & Placebo & Evo & Placebo & Evo & Placebo & Evo & Eze & Evo \\
\hline Diabetes & $\mathrm{N}=11$ & $\mathrm{~N}=17$ & $\mathrm{~N}=16$ & $\mathrm{~N}=17$ & $\mathrm{~N}=44$ & $\mathrm{~N}=18$ & $\mathrm{~N}=29$ & $\mathrm{~N}=34$ & $\mathrm{~N}=13$ & $\mathrm{~N}=41$ & $\mathrm{~N}=14$ & $\mathrm{~N}=35$ & $\mathrm{~N}=22$ & $\mathrm{~N}=39$ & $\mathrm{~N}=27$ & $\mathrm{~N}=36$ \\
\hline $\begin{array}{l}\text { LS mean } \\
(\mathrm{SE})\end{array}$ & $\begin{array}{c}1 \cdot 6 \\
(9 \cdot 2) \\
\end{array}$ & $\begin{array}{l}-39 \cdot 0 \\
(7 \cdot 1)\end{array}$ & $\begin{array}{c}9 \cdot 1 \\
(6 \cdot 8) \\
\end{array}$ & $\begin{array}{l}-7 \cdot 5 \\
(6 \cdot 9) \\
\end{array}$ & $\begin{array}{l}-49 \cdot 1 \\
(4 \cdot 5) \\
\end{array}$ & $\begin{array}{l}-3 \cdot 2 \\
(6 \cdot 2) \\
\end{array}$ & $\begin{array}{c}-22 \cdot 8 \\
(4 \cdot 8) \\
\end{array}$ & $\begin{array}{c}-47 \cdot 6 \\
(4 \cdot 4) \\
\end{array}$ & $\begin{array}{c}2 \cdot 4 \\
(4.9) \\
\end{array}$ & $\begin{array}{l}-54 \cdot 5 \\
(3 \cdot 1) \\
\end{array}$ & $\begin{array}{l}4.7 \\
(9.5) \\
\end{array}$ & $\begin{array}{l}-47 \cdot 9 \\
(7 \cdot 0) \\
\end{array}$ & $\begin{array}{l}14.9 \\
(7.7) \\
\end{array}$ & $\begin{array}{l}-53 \cdot 8 \\
(6 \cdot 9) \\
\end{array}$ & $\begin{array}{l}-11.9 \\
(2 \cdot 8) \\
\end{array}$ & $\begin{array}{r}-46 \cdot 8 \\
(2 \cdot 4) \\
\end{array}$ \\
\hline $95 \% \mathrm{CI}$ & $\begin{array}{c}(-17 \cdot 3, \\
20 \cdot 5)\end{array}$ & $\begin{array}{l}(-53 \cdot 6, \\
-24 \cdot 4) \\
\end{array}$ & $\begin{array}{l}(-4 \cdot 5, \\
22 \cdot 7) \\
\end{array}$ & $\begin{array}{c}(-21 \cdot 1, \\
6 \cdot 2) \\
\end{array}$ & $\begin{array}{l}(-58 \cdot 2 \\
-40 \cdot 1) \\
\end{array}$ & $\begin{array}{c}(-15 \cdot 6 \\
9 \cdot 1) \\
\end{array}$ & $\begin{array}{l}-32 \cdot 3 \\
-13 \cdot 3) \\
\end{array}$ & $\begin{array}{l}-56 \cdot 3 \\
-38 \cdot 9) \\
\end{array}$ & $\begin{array}{l}(-7 \cdot 4, \\
12 \cdot 3) \\
\end{array}$ & $\begin{array}{l}(-60 \cdot 7, \\
-48 \cdot 4) \\
\end{array}$ & $\begin{array}{c}(-14 \cdot 6, \\
24 \cdot 0) \\
\end{array}$ & $\begin{array}{l}(-61 \cdot 9 \\
-33 \cdot 8) \\
\end{array}$ & $\begin{array}{l}(-0 \cdot 5, \\
30 \cdot 3) \\
\end{array}$ & $\begin{array}{l}(-67 \cdot 6, \\
-40 \cdot 0) \\
\end{array}$ & $\begin{array}{c}(-17 \cdot 5, \\
-6 \cdot 2) \\
\end{array}$ & $\begin{array}{l}(-51 \cdot 5, \\
-42 \cdot 0) \\
\end{array}$ \\
\hline $\begin{array}{c}\text { Non - } \\
\text { Diabetes }\end{array}$ & $\mathrm{N}=98$ & $\mathrm{~N}=203$ & $\mathrm{~N}=95$ & $\mathrm{~N}=94$ & $\mathrm{~N}=176$ & $\mathrm{~N}=92$ & $\mathrm{~N}=81$ & $\mathrm{~N}=185$ & $\mathrm{~N}=102$ & $\mathrm{~N}=187$ & $\mathrm{~N}=97$ & $\mathrm{~N}=188$ & $\mathrm{~N}=89$ & $\mathrm{~N}=188$ & $\mathrm{~N}=75$ & $\mathrm{~N}=169$ \\
\hline $\begin{array}{l}\text { LS mean } \\
(\mathrm{SE})\end{array}$ & $\begin{array}{c}2 \cdot 1 \\
(1 \cdot 9)\end{array}$ & $\begin{array}{l}-54 \cdot 1 \\
(1 \cdot 3)\end{array}$ & $\begin{array}{c}4 \cdot 3 \\
(1 \cdot 7)\end{array}$ & $\begin{array}{r}-18 \cdot 3 \\
(1 \cdot 8) \\
\end{array}$ & $\begin{array}{l}-54 \cdot 5 \\
(1 \cdot 3) \\
\end{array}$ & $\begin{array}{l}13 \cdot 7 \\
(2 \cdot 9)\end{array}$ & $\begin{aligned}-13 \cdot 3 \\
(3 \cdot 0) \\
\end{aligned}$ & $\begin{aligned}-53 \cdot 4 \\
(2 \cdot 0)\end{aligned}$ & $\begin{array}{c}7 \cdot 7 \\
(1.9) \\
\end{array}$ & $\begin{array}{l}-50 \cdot 9 \\
(1 \cdot 4) \\
\end{array}$ & $\begin{array}{c}6 \cdot 0 \\
(2 \cdot 4)\end{array}$ & $\begin{array}{r}-49 \cdot 3 \\
(1 \cdot 7) \\
\end{array}$ & $\begin{array}{l}2 \cdot 4 \\
(2 \cdot 8)\end{array}$ & $\begin{array}{c}-53 \cdot 6 \\
(2 \cdot 2) \\
\end{array}$ & $\begin{array}{r}-15 \cdot 7 \\
(1 \cdot 8)\end{array}$ & $\begin{array}{r}-47 \cdot 5 \\
(1 \cdot 3) \\
\end{array}$ \\
\hline $95 \% \mathrm{CI}$ & $\begin{array}{c}(-1 \cdot 9, \\
5 \cdot 9)\end{array}$ & $\begin{array}{l}(-56 \cdot 8, \\
-51 \cdot 8)\end{array}$ & $\begin{array}{l}(0 \cdot 9 \\
7 \cdot 7)\end{array}$ & $\begin{array}{l}(-21 \cdot 7, \\
-14 \cdot 8)\end{array}$ & $\begin{array}{l}(-57 \cdot 0 \\
-52 \cdot 0)\end{array}$ & $\begin{array}{l}(7 \cdot 9 \\
19 \cdot 4)\end{array}$ & $\begin{array}{c}(-19 \cdot 3, \\
-7 \cdot 4)\end{array}$ & $\begin{array}{l}(-57 \cdot 4, \\
-49 \cdot 5)\end{array}$ & $\begin{array}{l}(4 \cdot 0, \\
11 \cdot 3)\end{array}$ & $\begin{array}{l}(-53 \cdot 7, \\
-48 \cdot 2)\end{array}$ & $\begin{array}{l}(1 \cdot 3, \\
10 \cdot 8)\end{array}$ & $\begin{array}{l}(-52 \cdot 6 \\
-45 \cdot 9)\end{array}$ & $\begin{array}{c}(-3 \cdot 1, \\
7 \cdot 9)\end{array}$ & $\begin{array}{l}(-57 \cdot 9 \\
-49 \cdot 2)\end{array}$ & $\begin{array}{l}(-19 \cdot 1, \\
-12 \cdot 2)\end{array}$ & $\begin{array}{l}(-50 \cdot 0, \\
-45 \cdot 1)\end{array}$ \\
\hline \multicolumn{17}{|c|}{ Total Cholesterol } \\
\hline & \multicolumn{2}{|c|}{ RUTHERFORD-2 } & \multicolumn{3}{|c|}{ LAPLACE-2 Atorva 10mg cohort } & \multicolumn{3}{|c|}{$\begin{array}{c}\text { LAPLACE-2 Atorva 80mg } \\
\text { cohort }\end{array}$} & \multicolumn{2}{|c|}{$\begin{array}{c}\text { LAPLACE-2 Rosuva } \\
\text { 5mg cohort }\end{array}$} & \multicolumn{2}{|c|}{$\begin{array}{c}\text { LAPLACE-2 Rosuva } \\
40 \mathrm{mg} \text { cohort }\end{array}$} & \multicolumn{2}{|c|}{$\begin{array}{c}\text { LAPLACE-2 Simva } \\
\text { 40mg cohort }\end{array}$} & \multicolumn{2}{|c|}{ GAUSS-2 } \\
\hline & Placebo & Evo & Placebo & Eze & Evo & Placebo & Eze & Evo & Placebo & Evo & Placebo & Evo & Placebo & Evo & Eze & Evo \\
\hline
\end{tabular}




\begin{tabular}{|c|c|c|c|c|c|c|c|c|c|c|c|c|c|c|c|c|}
\hline Diabetes & $\mathrm{N}=11$ & $\mathrm{~N}=17$ & $\mathrm{~N}=16$ & $\mathrm{~N}=17$ & $\mathrm{~N}=44$ & $\mathrm{~N}=18$ & $\mathrm{~N}=29$ & $\mathrm{~N}=34$ & $\mathrm{~N}=13$ & $\mathrm{~N}=41$ & $\mathrm{~N}=14$ & $\mathrm{~N}=35$ & $\mathrm{~N}=22$ & $\mathrm{~N}=39$ & $\mathrm{~N}=27$ & $\mathrm{~N}=36$ \\
\hline $\begin{array}{l}\text { LS mean } \\
(\mathrm{SE})\end{array}$ & $\begin{array}{c}-0 \cdot 6 \\
(7 \cdot 1) \\
\end{array}$ & $\begin{array}{l}-31 \cdot 0 \\
(5 \cdot 4)\end{array}$ & $\begin{array}{c}6 \cdot 8 \\
(4 \cdot 9) \\
\end{array}$ & $\begin{array}{l}-7 \cdot 0 \\
(4 \cdot 9) \\
\end{array}$ & $\begin{array}{c}-34 \cdot 4 \\
(3 \cdot 2) \\
\end{array}$ & $\begin{array}{l}-4 \cdot 0 \\
(4 \cdot 9) \\
\end{array}$ & $\begin{array}{c}-17 \cdot 5 \\
(3 \cdot 7) \\
\end{array}$ & $\begin{array}{c}-32.5 \\
(3.4) \\
\end{array}$ & $\begin{array}{c}0 \cdot 8 \\
(3 \cdot 4) \\
\end{array}$ & $\begin{array}{l}-38 \cdot 3 \\
(2 \cdot 2) \\
\end{array}$ & $\begin{array}{c}3 \cdot 6 \\
(6 \cdot 9) \\
\end{array}$ & $\begin{array}{c}-30 \cdot 2 \\
(5 \cdot 1) \\
\end{array}$ & $\begin{array}{c}9 \cdot 2 \\
(5 \cdot 5) \\
\end{array}$ & $\begin{array}{r}-39 \cdot 5 \\
(4 \cdot 9) \\
\end{array}$ & $\begin{array}{c}-11 \cdot 2 \\
(2 \cdot 4) \\
\end{array}$ & $\begin{array}{l}-37 \cdot 8 \\
(2 \cdot 0) \\
\end{array}$ \\
\hline $95 \% \mathrm{CI}$ & $\begin{array}{c}(-15 \cdot 1, \\
13 \cdot 9)\end{array}$ & $\begin{array}{l}-42 \cdot 2, \\
-19 \cdot 8) \\
\end{array}$ & $\begin{array}{l}(-3 \cdot 0, \\
16 \cdot 5) \\
\end{array}$ & $\begin{array}{c}(-16 \cdot 8, \\
2 \cdot 8)\end{array}$ & $\begin{array}{l}(-40 \cdot 8, \\
-27 \cdot 9)\end{array}$ & $\begin{array}{c}(-13 \cdot 6, \\
5 \cdot 7)\end{array}$ & $\begin{array}{l}(-24 \cdot 9, \\
-10 \cdot 0)\end{array}$ & $\begin{array}{l}(-39 \cdot 3, \\
-25 \cdot 7) \\
\end{array}$ & $\begin{array}{c}(-6 \cdot 0, \\
7 \cdot 7)\end{array}$ & $\begin{array}{l}(-42 \cdot 7, \\
-33 \cdot 9) \\
\end{array}$ & $\begin{array}{c}(-10 \cdot 4, \\
17 \cdot 6) \\
\end{array}$ & $\begin{array}{l}(-40 \cdot 3, \\
-20 \cdot 0)\end{array}$ & $\begin{array}{l}(-1 \cdot 8, \\
20 \cdot 2) \\
\end{array}$ & $\begin{array}{l}(-49 \cdot 3, \\
-29 \cdot 7)\end{array}$ & $\begin{array}{c}-15 \cdot 9, \\
-6 \cdot 4)\end{array}$ & $\begin{array}{c}(-41 \cdot 8, \\
-33 \cdot 8) \\
\end{array}$ \\
\hline $\begin{array}{c}\text { Non- } \\
\text { Diabetes }\end{array}$ & $\mathrm{N}=98$ & $\mathrm{~N}=203$ & $\mathrm{~N}=95$ & $\mathrm{~N}=94$ & $\mathrm{~N}=176$ & $\mathrm{~N}=92$ & $\mathrm{~N}=81$ & $\mathrm{~N}=185$ & $\mathrm{~N}=102$ & $\mathrm{~N}=187$ & $\mathrm{~N}=97$ & $\mathrm{~N}=188$ & $\mathrm{~N}=89$ & $\mathrm{~N}=188$ & $\mathrm{~N}=75$ & $\mathrm{~N}=169$ \\
\hline $\begin{array}{c}\text { LS mean } \\
(\mathrm{SE})\end{array}$ & $\begin{array}{c}0 \cdot 7 \\
(1.5) \\
\end{array}$ & $\begin{array}{l}-40 \cdot 6 \\
(1 \cdot 1) \\
\end{array}$ & $\begin{array}{c}2 \cdot 6 \\
(1.4) \\
\end{array}$ & $\begin{array}{c}-13.9 \\
(1.4) \\
\end{array}$ & $\begin{array}{c}-38 \cdot 0 \\
(1 \cdot 0) \\
\end{array}$ & $\begin{array}{l}10 \cdot 1 \\
(2 \cdot 1) \\
\end{array}$ & $\begin{array}{l}-8 \cdot 8 \\
(2 \cdot 2) \\
\end{array}$ & $\begin{array}{c}-34.8 \\
(1.5) \\
\end{array}$ & $\begin{array}{c}5 \cdot 3 \\
(1 \cdot 4) \\
\end{array}$ & $\begin{array}{l}-35 \cdot 8 \\
(1 \cdot 0) \\
\end{array}$ & $\begin{array}{c}2 \cdot 7 \\
(1.6) \\
\end{array}$ & $\begin{array}{c}-31 \cdot 8 \\
(1 \cdot 1) \\
\end{array}$ & $\begin{array}{c}0 \cdot 1 \\
(2 \cdot 2) \\
\end{array}$ & $\begin{array}{l}-37.5 \\
(1.7) \\
\end{array}$ & $\begin{array}{c}-12 \cdot 3 \\
(1.5) \\
\end{array}$ & $\begin{array}{l}-37.2 \\
(1.0) \\
\end{array}$ \\
\hline $95 \% \mathrm{CI}$ & $\begin{array}{c}(-2 \cdot 3, \\
3 \cdot 7) \\
\end{array}$ & $\begin{array}{l}(-42 \cdot 7, \\
-38 \cdot 5) \\
\end{array}$ & $\begin{array}{c}(-0 \cdot 1, \\
5 \cdot 3) \\
\end{array}$ & $\begin{array}{l}(-16 \cdot 7, \\
-11 \cdot 2) \\
\end{array}$ & $\begin{array}{l}(-39 \cdot 9, \\
-36 \cdot 0) \\
\end{array}$ & $\begin{array}{l}6 \cdot 0, \\
14 \cdot 1) \\
\end{array}$ & $\begin{array}{c}-13 \cdot 1, \\
-4 \cdot 6) \\
\end{array}$ & $\begin{array}{l}(-37 \cdot 7, \\
-32 \cdot 0) \\
\end{array}$ & $\begin{array}{l}(2 \cdot 5, \\
8 \cdot 0) \\
\end{array}$ & $\begin{array}{l}(-37 \cdot 8, \\
-33 \cdot 8) \\
\end{array}$ & $\begin{array}{c}(-0 \cdot 5 \\
5 \cdot 8) \\
\end{array}$ & $\begin{array}{l}(-34 \cdot 1, \\
-29 \cdot 6) \\
\end{array}$ & $\begin{array}{c}(-4 \cdot 2, \\
4 \cdot 3) \\
\end{array}$ & $\begin{array}{l}(-41 \cdot 0, \\
-34 \cdot 1) \\
\end{array}$ & $\begin{array}{c}-15 \cdot 2, \\
-9 \cdot 4) \\
\end{array}$ & $\begin{array}{l}(-39 \cdot 2, \\
-35 \cdot 1) \\
\end{array}$ \\
\hline \multicolumn{17}{|c|}{ Triglycerides } \\
\hline & \multicolumn{2}{|c|}{ RUTHERFORD-2 } & \multicolumn{3}{|c|}{ LAPLACE-2 Atorva 10mg cohort } & \multicolumn{3}{|c|}{$\begin{array}{l}\text { LAPLACE-2 Atorva } 80 \mathrm{mg} \\
\text { cohort }\end{array}$} & \multicolumn{2}{|c|}{$\begin{array}{l}\text { LAPLACE-2 Rosuva } \\
\text { 5mg cohort } \\
\end{array}$} & \multicolumn{2}{|c|}{$\begin{array}{l}\text { LAPLACE-2 Rosuva } \\
\text { 40mg cohort }\end{array}$} & \multicolumn{2}{|c|}{$\begin{array}{c}\text { LAPLACE-2 Simva } \\
\text { 40mg cohort }\end{array}$} & \multicolumn{2}{|c|}{ GAUSS-2 } \\
\hline & Placebo & Evo & Placebo & Eze & Evo & Placebo & Eze & Evo & Placebo & Evo & Placebo & Evo & Placebo & Evo & Eze & Evo \\
\hline Diabetes & $\mathrm{N}=11$ & $\mathrm{~N}=17$ & $\mathrm{~N}=16$ & $\mathrm{~N}=17$ & $\mathrm{~N}=44$ & $\mathrm{~N}=18$ & $\mathrm{~N}=29$ & $\mathrm{~N}=34$ & $\mathrm{~N}=13$ & $\mathrm{~N}=41$ & $\mathrm{~N}=14$ & $\mathrm{~N}=35$ & $\mathrm{~N}=22$ & $\mathrm{~N}=39$ & $\mathrm{~N}=27$ & $\mathrm{~N}=36$ \\
\hline $\begin{array}{l}\text { LS mean } \\
(\mathrm{SE})\end{array}$ & $\begin{array}{l}16 \cdot 9 \\
(11.9) \\
\end{array}$ & $\begin{array}{c}2 \cdot 2 \\
(9 \cdot 1) \\
\end{array}$ & $\begin{array}{c}1 \cdot 9 \\
(10 \cdot 0) \\
\end{array}$ & $\begin{array}{c}16 \cdot 0 \\
(10 \cdot 1) \\
\end{array}$ & $\begin{array}{l}-8 \cdot 1 \\
(6 \cdot 7) \\
\end{array}$ & $\begin{array}{c}3 \cdot 1 \\
(9 \cdot 8) \\
\end{array}$ & $\begin{array}{l}-10 \cdot 5 \\
(7 \cdot 6) \\
\end{array}$ & $\begin{array}{l}-8 \cdot 7 \\
(6 \cdot 9) \\
\end{array}$ & $\begin{array}{c}12 \cdot 2 \\
(12 \cdot 7) \\
\end{array}$ & $\begin{array}{l}-16 \cdot 9 \\
(7 \cdot 3) \\
\end{array}$ & $\begin{array}{c}4 \cdot 4 \\
(10 \cdot 8) \\
\end{array}$ & $\begin{array}{l}-20 \cdot 9 \\
(8 \cdot 4) \\
\end{array}$ & $\begin{array}{l}14 \cdot 0 \\
(9 \cdot 9) \\
\end{array}$ & $\begin{array}{l}-29 \cdot 2 \\
(8 \cdot 8) \\
\end{array}$ & $\begin{array}{l}-2 \cdot 0 \\
(7 \cdot 9) \\
\end{array}$ & $\begin{array}{l}-8 \cdot 9 \\
(6 \cdot 7) \\
\end{array}$ \\
\hline $95 \% \mathrm{CI}$ & $\begin{array}{l}(-7 \cdot 5 \\
41 \cdot 2)\end{array}$ & $\begin{array}{l}(-16 \cdot 5 \\
21 \cdot 0)\end{array}$ & $\begin{array}{l}(-18 \cdot 1 \\
21 \cdot 9)\end{array}$ & $\begin{array}{l}(-4 \cdot 2, \\
36 \cdot 1)\end{array}$ & $\begin{array}{c}(-21 \cdot 3 \\
5 \cdot 2)\end{array}$ & $\begin{array}{c}(-16 \cdot 3 \\
22 \cdot 6)\end{array}$ & $\begin{array}{l}(-25 \cdot 7 \\
4 \cdot 7)\end{array}$ & $\begin{array}{l}(-22 \cdot 5 \\
5 \cdot 1)\end{array}$ & $\begin{array}{c}(-13 \cdot 4, \\
37 \cdot 7)\end{array}$ & $\begin{array}{l}(-31 \cdot 6 \\
-2 \cdot 2)\end{array}$ & $\begin{array}{l}(-17 \cdot 4, \\
26 \cdot 2)\end{array}$ & $\begin{array}{l}(-37 \cdot 7 \\
-4 \cdot 0)\end{array}$ & $\begin{array}{l}(-5 \cdot 8, \\
33 \cdot 9)\end{array}$ & $\begin{array}{l}(-46 \cdot 8 \\
-11 \cdot 6)\end{array}$ & $\begin{array}{c}(-17 \cdot 8, \\
13 \cdot 7)\end{array}$ & $\begin{array}{c}(-22 \cdot 3, \\
4 \cdot 5)\end{array}$ \\
\hline $\begin{array}{c}\text { Non- } \\
\text { Diabetes }\end{array}$ & $\mathrm{N}=98$ & $\mathrm{~N}=203$ & $\mathrm{~N}=95$ & $\mathrm{~N}=94$ & $\mathrm{~N}=176$ & $\mathrm{~N}=92$ & $\mathrm{~N}=81$ & $\mathrm{~N}=185$ & $\mathrm{~N}=102$ & $\mathrm{~N}=187$ & $\mathrm{~N}=97$ & $\mathrm{~N}=188$ & $\mathrm{~N}=89$ & $\mathrm{~N}=188$ & $\mathrm{~N}=75$ & $\mathrm{~N}=169$ \\
\hline $\begin{array}{l}\text { LS mean } \\
(\mathrm{SE})\end{array}$ & $\begin{array}{c}3 \cdot 3 \\
(2 \cdot 8) \\
\end{array}$ & $\begin{array}{l}-11.8 \\
(1.9) \\
\end{array}$ & $\begin{array}{l}12 \cdot 1 \\
(4 \cdot 3) \\
\end{array}$ & $\begin{array}{c}-0 \cdot 4 \\
(4 \cdot 4) \\
\end{array}$ & $\begin{array}{l}-9 \cdot 5 \\
(3 \cdot 2) \\
\end{array}$ & $\begin{array}{c}8 \cdot 1 \\
(3 \cdot 6) \\
\end{array}$ & $\begin{array}{l}-3 \cdot 5 \\
(3 \cdot 8) \\
\end{array}$ & $\begin{array}{l}-5 \cdot 4 \\
(2 \cdot 5) \\
\end{array}$ & $\begin{array}{l}13 \cdot 4 \\
(4 \cdot 1) \\
\end{array}$ & $\begin{array}{c}-4 \cdot 0 \\
(3 \cdot 1) \\
\end{array}$ & $\begin{array}{l}10 \cdot 5 \\
(3 \cdot 3) \\
\end{array}$ & $\begin{array}{l}-6 \cdot 6 \\
(2 \cdot 4) \\
\end{array}$ & $\begin{array}{l}11 \cdot 0 \\
(5 \cdot 8) \\
\end{array}$ & $\begin{array}{l}-11 \cdot 0 \\
(4 \cdot 8) \\
\end{array}$ & $\begin{array}{l}-2 \cdot 8 \\
(3 \cdot 9) \\
\end{array}$ & $\begin{array}{l}-2 \cdot 1 \\
(2 \cdot 8) \\
\end{array}$ \\
\hline $95 \% \mathrm{CI}$ & $\begin{array}{c}(-2 \cdot 1, \\
8 \cdot 8) \\
\end{array}$ & $\begin{array}{c}-15 \cdot 5 \\
-8 \cdot 0) \\
\end{array}$ & $\begin{array}{l}(3 \cdot 6, \\
20 \cdot 6) \\
\end{array}$ & $\begin{array}{c}(-9 \cdot 0 \\
8 \cdot 2) \\
\end{array}$ & $\begin{array}{c}(-15 \cdot 8, \\
-3 \cdot 3) \\
\end{array}$ & $\begin{array}{l}(0 \cdot 9, \\
15 \cdot 3) \\
\end{array}$ & $\begin{array}{c}(-10 \cdot 9, \\
4 \cdot 0) \\
\end{array}$ & $\begin{array}{c}(-10 \cdot 3 \\
-0 \cdot 4) \\
\end{array}$ & $\begin{array}{l}(5 \cdot 2, \\
21 \cdot 5) \\
\end{array}$ & $\begin{array}{c}(-10 \cdot 1 \\
2 \cdot 1) \\
\end{array}$ & $\begin{array}{l}(3 \cdot 9, \\
17 \cdot 1) \\
\end{array}$ & $\begin{array}{c}(-11 \cdot 3 \\
-1 \cdot 9) \\
\end{array}$ & $\begin{array}{ll}(-0 \cdot 4, \\
22 \cdot 4) \\
\end{array}$ & $\begin{array}{c}(-20 \cdot 4, \\
-1 \cdot 7) \\
\end{array}$ & $\begin{array}{c}(-10 \cdot 5 \\
4 \cdot 9) \\
\end{array}$ & $\begin{array}{c}(-7 \cdot 5, \\
3 \cdot 3) \\
\end{array}$ \\
\hline \multicolumn{17}{|c|}{ HDL-cholesterol } \\
\hline & \multicolumn{2}{|c|}{ RUTHERFORD-2 } & \multicolumn{3}{|c|}{ LAPLACE-2 Atorva 10mg cohort } & \multicolumn{3}{|c|}{$\begin{array}{c}\text { LAPLACE-2 Atorva 80mg } \\
\text { cohort } \\
\end{array}$} & \multicolumn{2}{|c|}{$\begin{array}{l}\text { LAPLACE-2 Rosuva } \\
5 \mathrm{mg} \text { cohort }\end{array}$} & \multicolumn{2}{|c|}{$\begin{array}{c}\text { LAPLACE-2 Rosuva } \\
40 \mathrm{mg} \text { cohort }\end{array}$} & \multicolumn{2}{|c|}{$\begin{array}{c}\text { LAPLACE- } 2 \text { Simva } \\
\text { 40mg cohort } \\
\end{array}$} & \multicolumn{2}{|c|}{ GAUSS-2 } \\
\hline & Placebo & Evo & Placebo & Eze & Evo & Placebo & Eze & Evo & Placebo & Evo & Placebo & Evo & Placebo & Evo & Eze & Evo \\
\hline Diabetes & $\mathrm{N}=11$ & $\mathrm{~N}=17$ & $\mathrm{~N}=16$ & $\mathrm{~N}=17$ & $\mathrm{~N}=44$ & $\mathrm{~N}=18$ & $\mathrm{~N}=29$ & $\mathrm{~N}=34$ & $\mathrm{~N}=13$ & $\mathrm{~N}=41$ & $\mathrm{~N}=14$ & $\mathrm{~N}=35$ & $\mathrm{~N}=22$ & $\mathrm{~N}=39$ & $\mathrm{~N}=27$ & $\mathrm{~N}=36$ \\
\hline $\begin{array}{l}\text { LS mean } \\
(\mathrm{SE})\end{array}$ & $\begin{array}{l}-5 \cdot 2 \\
(6 \cdot 2) \\
\end{array}$ & $\begin{array}{l}11 \cdot 5 \\
(4 \cdot 8) \\
\end{array}$ & $\begin{array}{c}1 \cdot 5 \\
(3 \cdot 4) \\
\end{array}$ & $\begin{array}{l}-5 \cdot 0 \\
(3 \cdot 4) \\
\end{array}$ & $\begin{array}{c}4 \cdot 9 \\
(2 \cdot 2) \\
\end{array}$ & $\begin{array}{l}-3 \cdot 6 \\
(3 \cdot 6) \\
\end{array}$ & $\begin{array}{l}-2 \cdot 5 \\
(2 \cdot 8) \\
\end{array}$ & $\begin{array}{c}7 \cdot 7 \\
(2 \cdot 5) \\
\end{array}$ & $\begin{array}{l}-2 \cdot 3 \\
(4 \cdot 5) \\
\end{array}$ & $\begin{array}{l}10 \cdot 4 \\
(2 \cdot 8) \\
\end{array}$ & $\begin{array}{c}3 \cdot 0 \\
(4 \cdot 3) \\
\end{array}$ & $\begin{array}{c}7 \cdot 9 \\
(3 \cdot 4) \\
\end{array}$ & $\begin{array}{c}2 \cdot 2 \\
(3 \cdot 5)\end{array}$ & $\begin{array}{c}7 \cdot 6 \\
(3 \cdot 0)\end{array}$ & $\begin{array}{l}-1 \cdot 3 \\
(3 \cdot 1)\end{array}$ & $\begin{array}{l}4 \cdot 1 \\
(2 \cdot 6)\end{array}$ \\
\hline $95 \% \mathrm{CI}$ & $\begin{array}{c}(-17 \cdot 9 \\
7 \cdot 4) \\
\end{array}$ & $\begin{array}{l}(1 \cdot 6, \\
21 \cdot 4) \\
\end{array}$ & $\begin{array}{c}(-5 \cdot 2 \\
8 \cdot 3) \\
\end{array}$ & $\begin{array}{c}(-11 \cdot 8 \\
1 \cdot 8) \\
\end{array}$ & $\begin{array}{l}(0 \cdot 5, \\
9 \cdot 4) \\
\end{array}$ & $\begin{array}{c}(-10 \cdot 7, \\
3 \cdot 6) \\
\end{array}$ & $\begin{array}{c}(-8 \cdot 0, \\
3 \cdot 0) \\
\end{array}$ & $\begin{array}{l}(2 \cdot 6, \\
12 \cdot 7) \\
\end{array}$ & $\begin{array}{c}(-11 \cdot 4 \\
6 \cdot 7) \\
\end{array}$ & $\begin{array}{l}(4 \cdot 7, \\
16 \cdot 0) \\
\end{array}$ & $\begin{array}{l}(-5 \cdot 7, \\
11 \cdot 7) \\
\end{array}$ & $\begin{array}{l}(1 \cdot 1, \\
14 \cdot 6) \\
\end{array}$ & $\begin{array}{c}(-4 \cdot 8, \\
9 \cdot 2) \\
\end{array}$ & $\begin{array}{l}(1 \cdot 6, \\
13 \cdot 6) \\
\end{array}$ & $\begin{array}{c}(-7 \cdot 5 \\
5 \cdot 0) \\
\end{array}$ & $\begin{array}{c}(-1 \cdot 2 \\
9 \cdot 4) \\
\end{array}$ \\
\hline $\begin{array}{c}\text { Non - } \\
\text { Diabetes }\end{array}$ & $\mathrm{N}=98$ & $\mathrm{~N}=203$ & $\mathrm{~N}=95$ & $\mathrm{~N}=94$ & $\mathrm{~N}=176$ & $\mathrm{~N}=92$ & $\mathrm{~N}=81$ & $\mathrm{~N}=185$ & $\mathrm{~N}=102$ & $\mathrm{~N}=187$ & $\mathrm{~N}=97$ & $\mathrm{~N}=188$ & $\mathrm{~N}=89$ & $\mathrm{~N}=188$ & $\mathrm{~N}=75$ & $\mathrm{~N}=169$ \\
\hline $\begin{array}{c}\text { LS mean } \\
(\mathrm{SE})\end{array}$ & $\begin{array}{l}-2 \cdot 1 \\
(1 \cdot 6) \\
\end{array}$ & $\begin{array}{c}6 \cdot 5 \\
(1 \cdot 1) \\
\end{array}$ & $\begin{array}{l}-0.4 \\
(1.4) \\
\end{array}$ & $\begin{array}{l}-0.8 \\
(1.5) \\
\end{array}$ & $\begin{array}{c}7 \cdot 6 \\
(1 \cdot 1) \\
\end{array}$ & $\begin{array}{c}4 \cdot 1 \\
(1.5) \\
\end{array}$ & $\begin{array}{c}1.6 \\
(1.6) \\
\end{array}$ & $\begin{array}{c}8.4 \\
(1.0) \\
\end{array}$ & $\begin{array}{c}2 \cdot 0 \\
(1.8) \\
\end{array}$ & $\begin{array}{c}5 \cdot 5 \\
(1 \cdot 3) \\
\end{array}$ & $\begin{array}{c}-0.2 \\
(1.4) \\
\end{array}$ & $\begin{array}{c}4.9 \\
(1 \cdot 0) \\
\end{array}$ & $\begin{array}{l}-1 \cdot 4 \\
(2 \cdot 4) \\
\end{array}$ & $\begin{array}{c}8.7 \\
(1.9) \\
\end{array}$ & $\begin{array}{c}2.9 \\
(1.9) \\
\end{array}$ & $\begin{array}{c}6 \cdot 1 \\
(1 \cdot 3) \\
\end{array}$ \\
\hline $95 \% \mathrm{CI}$ & $(-5 \cdot 2$ & $(4 \cdot 4$ & $(-3 \cdot 3$ & $(-3 \cdot 7$ & $(5 \cdot 5$ & $(1 \cdot 1$, & $(-1 \cdot 4$ & $(6 \cdot 4$ & $(-1 \cdot 5$ & $(3 \cdot 0$ & $(-3 \cdot 0$ & $(2 \cdot 9$ & $(-6 \cdot 0$ & $(5 \cdot 0$ & $(-0 \cdot 8$ & $(3 \cdot 6$ \\
\hline
\end{tabular}




\begin{tabular}{|c|c|c|c|c|c|c|c|c|c|c|c|c|c|c|c|c|}
\hline & $\overline{1 \cdot 0)}$ & $8 \cdot 6)$ & $2 \cdot 4)$ & $2 \cdot 1)$ & $\overline{9 \cdot 7)}$ & $7 \cdot 0)$ & $4 \cdot 7)$ & $10 \cdot 5)$ & 5.4) & $8 \cdot 1)$ & $2 \cdot 7)$ & 6.9) & $3 \cdot 3)$ & 12.4) & $\overline{6 \cdot 5)}$ & $\overline{8 \cdot 7)}$ \\
\hline \multicolumn{17}{|c|}{ Lipoprotein(a) } \\
\hline & \multicolumn{2}{|c|}{ RUTHERFORD-2 } & \multicolumn{3}{|c|}{ LAPLACE-2 Atorva 10mg cohort } & \multicolumn{3}{|c|}{$\begin{array}{l}\text { LAPLACE-2 Atorva 80mg } \\
\text { cohort }\end{array}$} & \multicolumn{2}{|c|}{$\begin{array}{l}\text { LAPLACE- } 2 \text { Rosuva } \\
5 \mathrm{mg} \text { cohort }\end{array}$} & \multicolumn{2}{|c|}{$\begin{array}{l}\text { LAPLACE-2 Rosuva } \\
\text { 40mg cohort }\end{array}$} & \multicolumn{2}{|c|}{$\begin{array}{c}\text { LAPLACE-2 Simva } \\
\text { 40mg cohort }\end{array}$} & \multicolumn{2}{|c|}{ GAUSS-2 } \\
\hline & Placebo & Evo & Placebo & Eze & Evo & Placebo & Eze & Evo & Placebo & Evo & Placebo & Evo & Placebo & Evo & Eze & Evo \\
\hline Diabetes & $\mathrm{N}=11$ & $\mathrm{~N}=17$ & $\mathrm{~N}=16$ & $\mathrm{~N}=17$ & $\mathrm{~N}=44$ & $\mathrm{~N}=18$ & $\mathrm{~N}=29$ & $\mathrm{~N}=34$ & $\mathrm{~N}=13$ & $\mathrm{~N}=41$ & $\mathrm{~N}=14$ & $\mathrm{~N}=35$ & $\mathrm{~N}=22$ & $\mathrm{~N}=39$ & $\mathrm{~N}=27$ & $\mathrm{~N}=36$ \\
\hline $\begin{array}{l}\text { LS mean } \\
(\mathrm{SE})\end{array}$ & $\begin{array}{c}4 \cdot 6 \\
(8 \cdot 2) \\
\end{array}$ & $\begin{aligned}-29 \cdot 5 \\
(6 \cdot 0) \\
\end{aligned}$ & $\begin{array}{c}1 \cdot 2 \\
(7 \cdot 0)\end{array}$ & $\begin{array}{l}-5 \cdot 8 \\
(7 \cdot 5) \\
\end{array}$ & $\begin{array}{l}-22 \cdot 8 \\
(4 \cdot 8) \\
\end{array}$ & $\begin{array}{l}-0 \cdot 3 \\
(6 \cdot 9) \\
\end{array}$ & $\begin{array}{c}7 \cdot 5 \\
(5 \cdot 2) \\
\end{array}$ & $\begin{array}{l}-22 \cdot 0 \\
(4 \cdot 8) \\
\end{array}$ & $\begin{array}{c}8 \cdot 6 \\
(6 \cdot 4) \\
\end{array}$ & $\begin{array}{l}-24 \cdot 3 \\
(4 \cdot 3) \\
\end{array}$ & $\begin{array}{c}8 \cdot 3 \\
(7 \cdot 0) \\
\end{array}$ & $\begin{array}{l}-29 \cdot 0 \\
(5 \cdot 3) \\
\end{array}$ & $\begin{array}{l}-1 \cdot 2 \\
(7 \cdot 2) \\
\end{array}$ & $\begin{array}{c}-38 \cdot 0 \\
(6 \cdot 5) \\
\end{array}$ & $\begin{array}{c}2 \cdot 4 \\
(9 \cdot 9) \\
\end{array}$ & $\begin{array}{l}-30 \cdot 5 \\
(8 \cdot 1)\end{array}$ \\
\hline $95 \% \mathrm{CI}$ & $\begin{array}{l}(-12 \cdot 4 \\
21 \cdot 6)\end{array}$ & $\begin{array}{l}(-41 \cdot 8 \\
-17 \cdot 1)\end{array}$ & $\begin{array}{c}(-12 \cdot 8, \\
15 \cdot 2)\end{array}$ & $\begin{array}{c}(-20 \cdot 9) \\
9 \cdot 3)\end{array}$ & $\begin{array}{l}(-32 \cdot 3 \\
-13 \cdot 3)\end{array}$ & $\begin{array}{c}(-13 \cdot 9 \\
13 \cdot 4)\end{array}$ & $\begin{array}{l}(-2 \cdot 8, \\
17 \cdot 8)\end{array}$ & $\begin{array}{l}(-31 \cdot 5 \\
-12 \cdot 4)\end{array}$ & $\begin{array}{l}(-4 \cdot 3 \\
21 \cdot 5)\end{array}$ & $\begin{array}{r}(-32 \cdot 9 \\
-15 \cdot 6)\end{array}$ & $\begin{array}{l}(-5 \cdot 8 \\
22 \cdot 5)\end{array}$ & $\begin{array}{l}(-39 \cdot 6, \\
-18 \cdot 4)\end{array}$ & $\begin{array}{c}(-15 \cdot 6 \\
13 \cdot 2)\end{array}$ & $\begin{array}{l}(-51 \cdot 1 \\
-25 \cdot 0)\end{array}$ & $\begin{array}{c}(-17 \cdot 2 \\
22 \cdot 1)\end{array}$ & $\begin{array}{l}(-46 \cdot 7, \\
-14 \cdot 4)\end{array}$ \\
\hline $\begin{array}{c}\text { Non - } \\
\text { Diabetes }\end{array}$ & $\mathrm{N}=98$ & $\mathrm{~N}=203$ & $\mathrm{~N}=95$ & $\mathrm{~N}=94$ & $\mathrm{~N}=176$ & $\mathrm{~N}=92$ & $\mathrm{~N}=81$ & $\mathrm{~N}=185$ & $\mathrm{~N}=102$ & $\mathrm{~N}=187$ & $\mathrm{~N}=97$ & $\mathrm{~N}=188$ & $\mathrm{~N}=89$ & $\mathrm{~N}=188$ & $\mathrm{~N}=75$ & $\mathrm{~N}=169$ \\
\hline $\begin{array}{l}\text { LS mean } \\
\text { (SE) }\end{array}$ & $\begin{array}{c}7 \cdot 3 \\
(2 \cdot 4)\end{array}$ & $\begin{array}{c}-21 \cdot 3 \\
(1.6)\end{array}$ & $\begin{array}{c}3 \cdot 6 \\
(2 \cdot 5)\end{array}$ & $\begin{array}{c}7 \cdot 3 \\
(2 \cdot 6)\end{array}$ & $\begin{array}{c}-23 \cdot 1 \\
(1 \cdot 8)\end{array}$ & $\begin{array}{c}1 \cdot 8 \\
(2 \cdot 6)\end{array}$ & $\begin{array}{l}10 \cdot 1 \\
(2 \cdot 8)\end{array}$ & $\begin{array}{c}-25 \cdot 1 \\
(1.9)\end{array}$ & $\begin{array}{c}8 \cdot 1 \\
(2 \cdot 8)\end{array}$ & $\begin{array}{l}-22 \cdot 5 \\
(2 \cdot 1)\end{array}$ & $\begin{array}{c}9 \cdot 8 \\
(2.9)\end{array}$ & $\begin{array}{l}-24 \cdot 5 \\
(2 \cdot 0)\end{array}$ & $\begin{array}{l}-1 \cdot 0 \\
(4 \cdot 0)\end{array}$ & $\begin{array}{l}-29 \cdot 1 \\
(3 \cdot 3)\end{array}$ & $\begin{array}{c}1.4 \\
(2.9)\end{array}$ & $\begin{array}{l}-23 \cdot 3 \\
(2 \cdot 2)\end{array}$ \\
\hline $95 \% \mathrm{CI}$ & $\begin{array}{l}(2 \cdot 6, \\
11.9)\end{array}$ & $\begin{array}{l}(-24 \cdot 5, \\
-18 \cdot 1)\end{array}$ & $\begin{array}{c}(-1 \cdot 3 \\
8 \cdot 5)\end{array}$ & $\begin{array}{l}(2 \cdot 3, \\
12 \cdot 3)\end{array}$ & $\begin{array}{l}(-26 \cdot 7, \\
-19 \cdot 5)\end{array}$ & $\begin{array}{c}(-3 \cdot 4, \\
7 \cdot 0)\end{array}$ & $\begin{array}{l}(4 \cdot 7, \\
15 \cdot 6)\end{array}$ & $\begin{array}{l}(-28 \cdot 7, \\
-21 \cdot 4)\end{array}$ & $\begin{array}{l}(2 \cdot 7, \\
13 \cdot 6)\end{array}$ & $\begin{array}{l}(-26 \cdot 5, \\
-18 \cdot 4)\end{array}$ & $\begin{array}{l}(4 \cdot 2, \\
15 \cdot 5)\end{array}$ & $\begin{array}{l}(-28 \cdot 5, \\
-20 \cdot 5)\end{array}$ & $\begin{array}{c}(-8 \cdot 8, \\
6 \cdot 9)\end{array}$ & $\begin{array}{l}(-35 \cdot 7, \\
-22 \cdot 6)\end{array}$ & $\begin{array}{c}(-4 \cdot 4, \\
7 \cdot 2)\end{array}$ & $\begin{array}{l}(-27 \cdot 5, \\
-19 \cdot 0)\end{array}$ \\
\hline
\end{tabular}

$\mathrm{N}=$ number of subjects randomized and dosed in the full analysis set

Abbreviations: LS: least squares; SE: standard error; CI: confidence intervals; Evo: evolocumab; Eze: ezetimibe; atorva: atorvastatin; rosuva: rosuvastatin;

simva: simvastatin 
Supplementary Table 2. Percentage change in LDL-cholesterol in evolocumab- vs. placebo-treated patients at week 12

\begin{tabular}{|l|l|}
\hline & \multicolumn{1}{|c|}{ Patients with T2DM } \\
\hline INSULIN & $\mathrm{N}=39$ \\
On insulin & $-57 \cdot 4(-72 \cdot 0,-42 \cdot 8)$ \\
Mean $(95 \% \mathrm{CI})$ percentage change in LDL-C & $\mathrm{N}=247$ \\
Not on insulin & $-60 \cdot 5(-68 \cdot 8,-52 \cdot 2)$ \\
Mean $(95 \% \mathrm{CI})$ percentage change in LDL-C & $\mathrm{N}=124$ \\
\hline CVD & $-58 \cdot 6(-72 \cdot 2,-45 \cdot 0)$ \\
With CVD & $\mathrm{N}=162$ \\
Mean $(95 \% \mathrm{CI})$ percentage change in LDL-C & $-60 \cdot 5(-68 \cdot 4,-52 \cdot 5)$ \\
Without CVD & $\mathrm{N}=147$ \\
Mean $(95 \% \mathrm{CI})$ percentage change in LDL-C & $-56 \cdot 8(-67 \cdot 4,-46 \cdot 1)$ \\
\hline HbA1c & $\mathrm{N}=138$ \\
HbA1c $\geq$ baseline median $(6 \cdot 4 \%)$ & $-62 \cdot 1(-72 \cdot 4,-51 \cdot 7)$ \\
Mean $(95 \% \mathrm{CI})$ percentage change in LDL-C & $\mathrm{N}=237$ \\
HbA1c $<$ baseline median $(6 \cdot 4 \%)$ & $-58 \cdot 9(-67 \cdot 3,-50 \cdot 4)$ \\
Mean $(95 \% \mathrm{CI})$ percentage change in LDL-C & $\mathrm{N}=49$ \\
\hline eGFR & $-60 \cdot 1(-72 \cdot 9,-47 \cdot 3)$ \\
eGFR $\geq 60 \mathrm{~mL} / \mathrm{min} / 1 \cdot 73 \mathrm{~m}^{2}$ & \\
Mean $(95 \% \mathrm{CI})$ percentage change in LDL-C &
\end{tabular}

Data presented as mean $(95 \% \mathrm{CI})$ change from baseline

Abbreviations: CHD, coronary heart disease; CI, confidence interval; eGFR, estimated glomerular filtration rate; HbA1c, haemoglobin A1c; LDL, low-density lipoprotein 